\title{
Evaulation and Ranking of the Tank Focus Area Solid Liquid Separation Needs
}

by

D. J. McCabe

Westinghouse Savannah River Company

Savannah River Site

Aiken, South Carolina 29808

DOE Contract NO. DE-A C09-89SR18035.

This paper was prepared in connection with work done under the above contract number with the U.S.

Department of Energy. By acceptance of this paper, the publisher and/or recipient acknowledges the U.S.

Government's right to retain a nonexclusive, royalty-free license in and to any copyright covering this paper, along with the right to reproduce and to authorize others to reproduce all or part of the copyrighted paper.

$$
\text { do }
$$




\section{DISCLAIMER}

This report was prepared as an account of work sponsored by an ageacy of the United States Government. Neither the United States Government nor any agency thereof, nor any of their employees, makes any warranty. express or implied, or assumes any legal liability or responsibility for the accuracy, completeness, or usefulness of any information, apparatus, product, or process disclosed, or represents that its use would not infringe privately owned rights. Reference herein to any specific commercial product, process, or service by trade name, trademark, manufacturer, or otherwise does not necessarily constitute or imply its endorsement, recommendation, or favoring by the United States Government or any agency thereof. The views and opinions of authors expressed herein do not necessarily state or reflect those of the United States Government or any agency thereof.

This report has been reproduced directly from the best available copy.

Available to DOE and DOE contractors from the Office of Scientific and Techinical Information, P. O. Box 62, Oak Ridge, TN 37831: prices available from (615) $576-8401$.

Available to the public from the National Techaical Information Service. U. S. Department of Commerce, 5285 Port Royal Rd.. Springfield, VA 22161 


\section{DISCLAMMIER}

Portions of this document may be illegible in electronic image products. Images are produced from the best available original document. 
Distribution:

S.D. Fink, 773-A

W.L. Tamosaitis, 773-A

R.A. Peterson, 676-T

B.W. Walker, 676-15T

C.A. Nash, 676-15T

J.N. Brooke, 719-4A

M.S. Hay, 773-A

H.D. Harmon, 719-4A

W.B. Vanpelt, 241-119H

C.L. Leung, 241-119H

B.L. Lewis, 703-H

J.E. Marra, 703-H

R.A. Jacobs, 704-T

C.P. MCGinnis, ORNL

M.G. Schwenker, 703-H

N.F. Chapman, 704-99S

L.F. Landon, 704-T

B.A. Reynolds, PNI

J.G. Geeting, PNL

S.A. Barker, Hanford

R. Hunt, ORNL

T.E. Kent, ORNL

W.D. Bond, ORNL

R.R. Brunson, ORNL

J.H. Wilson, ORNL

Tech. Info. Mgmt, 703-43A

IWT file (A. Patterson, 773-A) 
WSRC-TR-95-0337

Revision 0

Keywords: In-Tank Precipitation, Mott

Eilter

Retention: Permanent

Evaluation and Ranking of the Tank Focus Area Solid Iiquid Separation Needs (U)

August 17, 1995

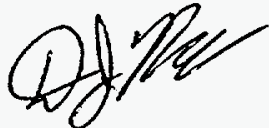

D.J. McCabe, 773-43A

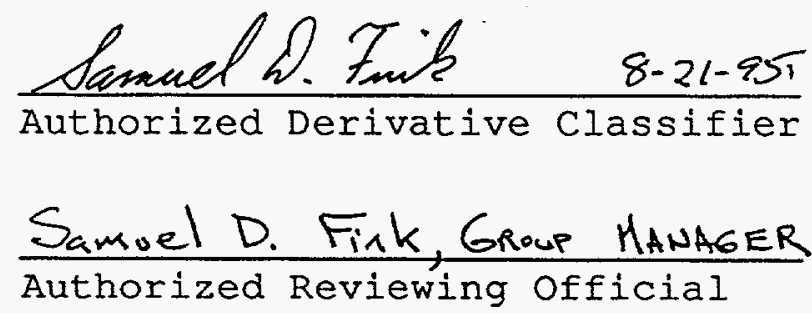

Savannah River Technology Center

Westinghouse Savannah River Company

Aiken, SC 29802

Prepared for the Department of Energy Office of Technology

Development, Technical Task Plan SR1-4-20-11 


\section{SUMMARY}

Proposed treatment processes for High Level Waste at Hanford and Oak Ridge National Laboratory (ORNL) include pretreatment to separate insoluble solids from the aqueous waste. Crossflow filtration, dead-end filtration, and setting are methods applicable to these separations. Testing is needed for selection of the appropriate technique for each application. Crossflow filtration is most applicable to the ORNI Radiochemical Engineering Development Center (REDC) waste and the ORNL Newly Generated Low Level Liquid Waste (NGLLLW) treatment. In addition, the Hanford Tank Waste Remediation System (TWRS), ORNL Melton Valley Storage Tank (MVST) TRU Processing Facility, and the ORNI Gunite Tank program may require crossflow filtration. Backflushable cartridge filters are probably the best treatment method for the MVST supernate cesium removal program and part of the NGLILW treatment process. Some of the streams require a combination of methods, such as a coarse sèttling and a polishing filtration stage.

Solid/Iiquid separation work conducted at the Savannah River Site (SRS), ORNL, Hanford, and West Valley is summarized and the applicability to current needs discussed. General information about crossflow filtration and design of filtration experiments is also included. 
Table of Contents

Acronym Definitions..................... 4

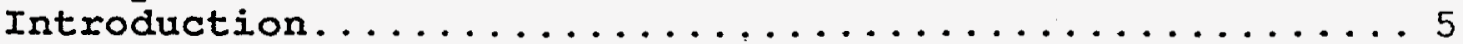

General Information on Solid/Liquid separation.... 6 Solid/Liquid Separation Methods Considered............6 Crossflow Filtration Equipment at Savannah River Site....6

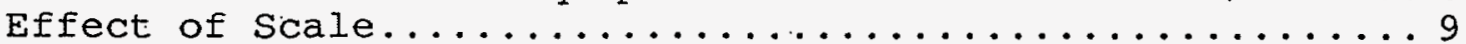

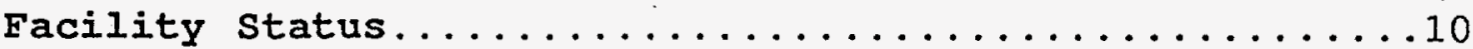

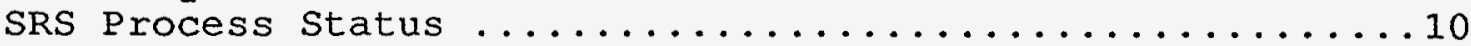

West Valley PUREX Sludge Treatment Process............11

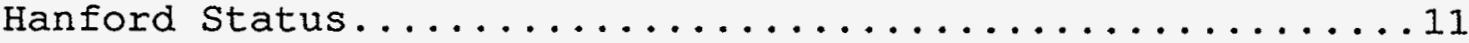

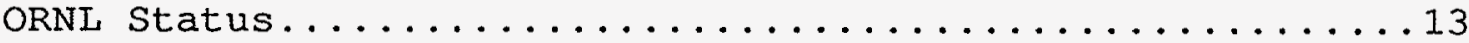

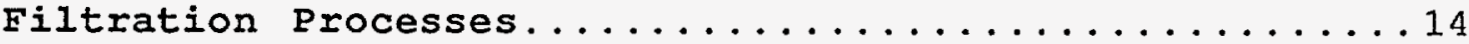

Flowsheet Considerations................... 17

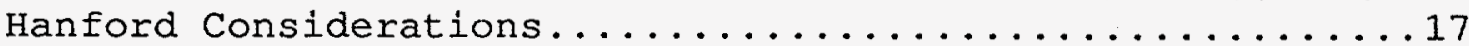

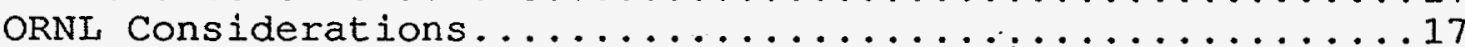

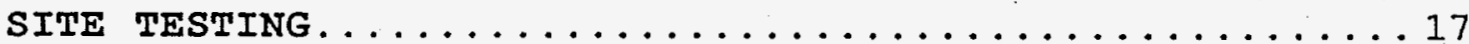

SRS Effluent Treatment Facility Tests.................

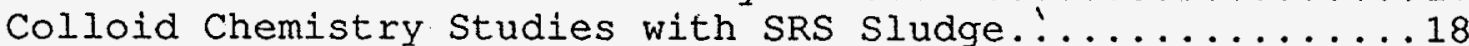

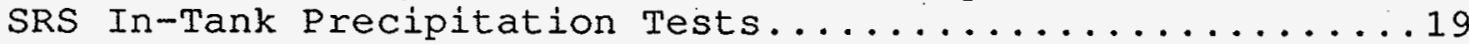

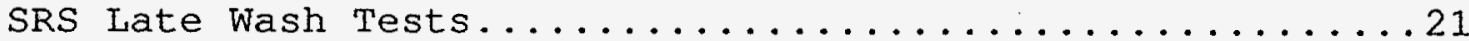

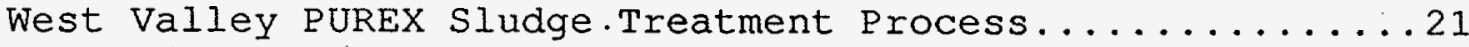

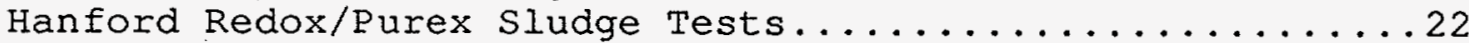

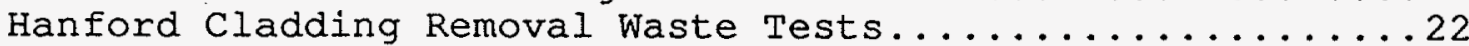

Hanford Neutralized Current Acid Waste Tests...........23

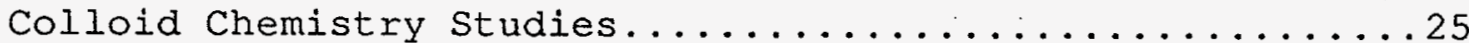

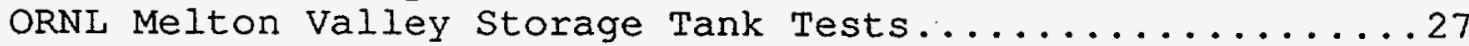

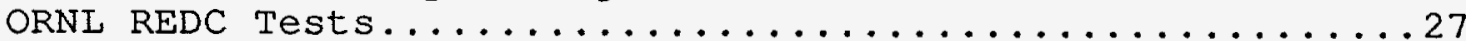

ORNI Newly Generated Low Level Liquid Waste Tests.......28

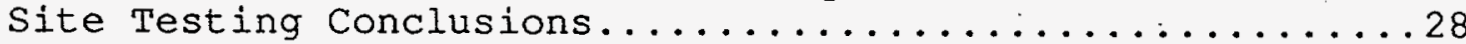

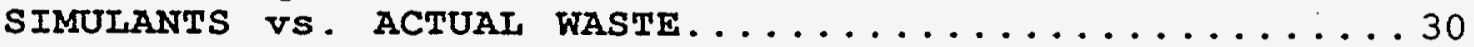

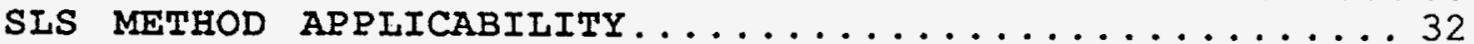

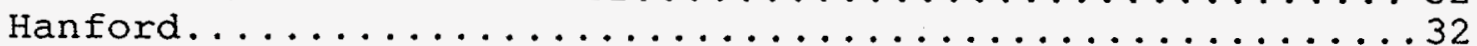

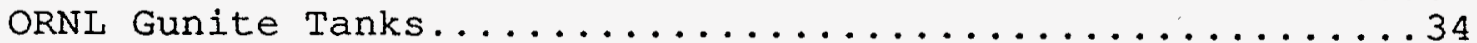

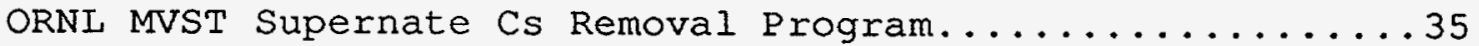

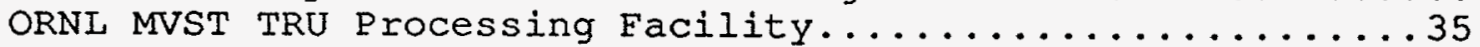

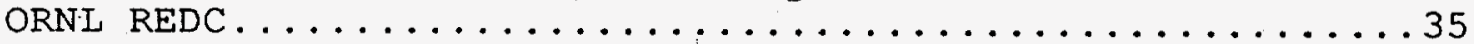

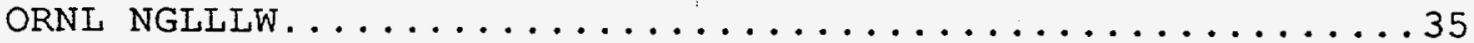

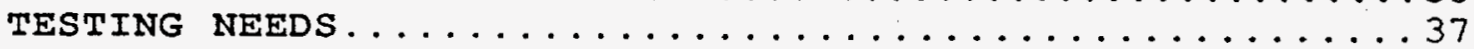

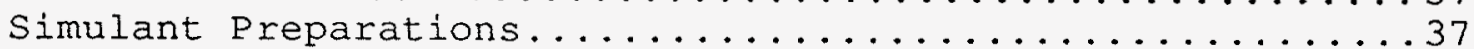

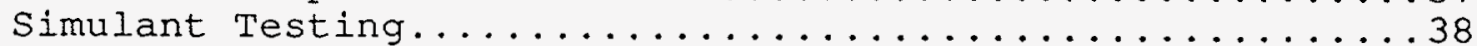

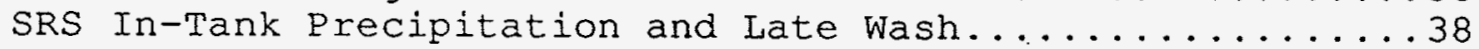

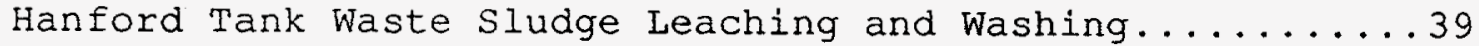

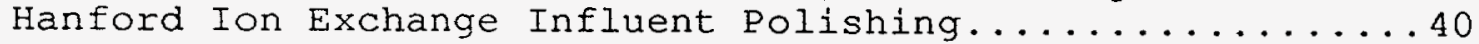

Hanford Ion Exchange Effluent Fines Removal...........42

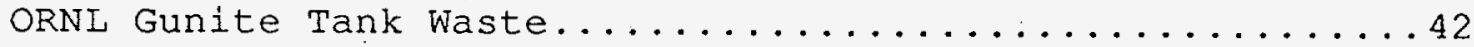

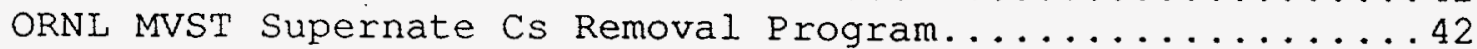

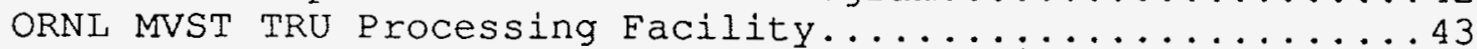

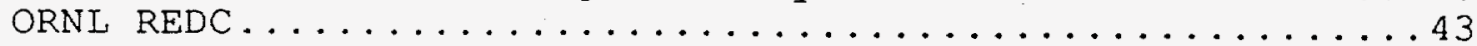

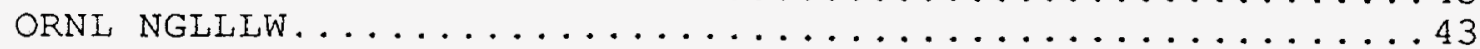

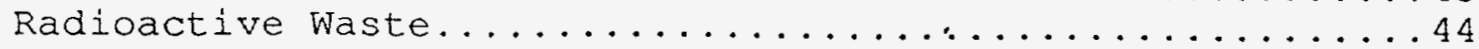

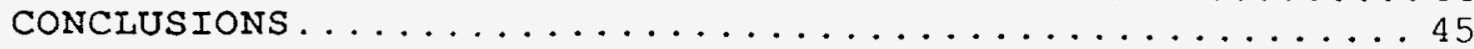

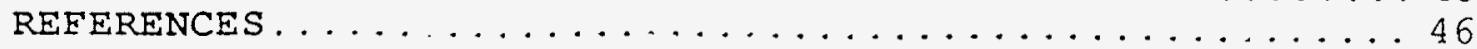




\section{Acronym Definitions}

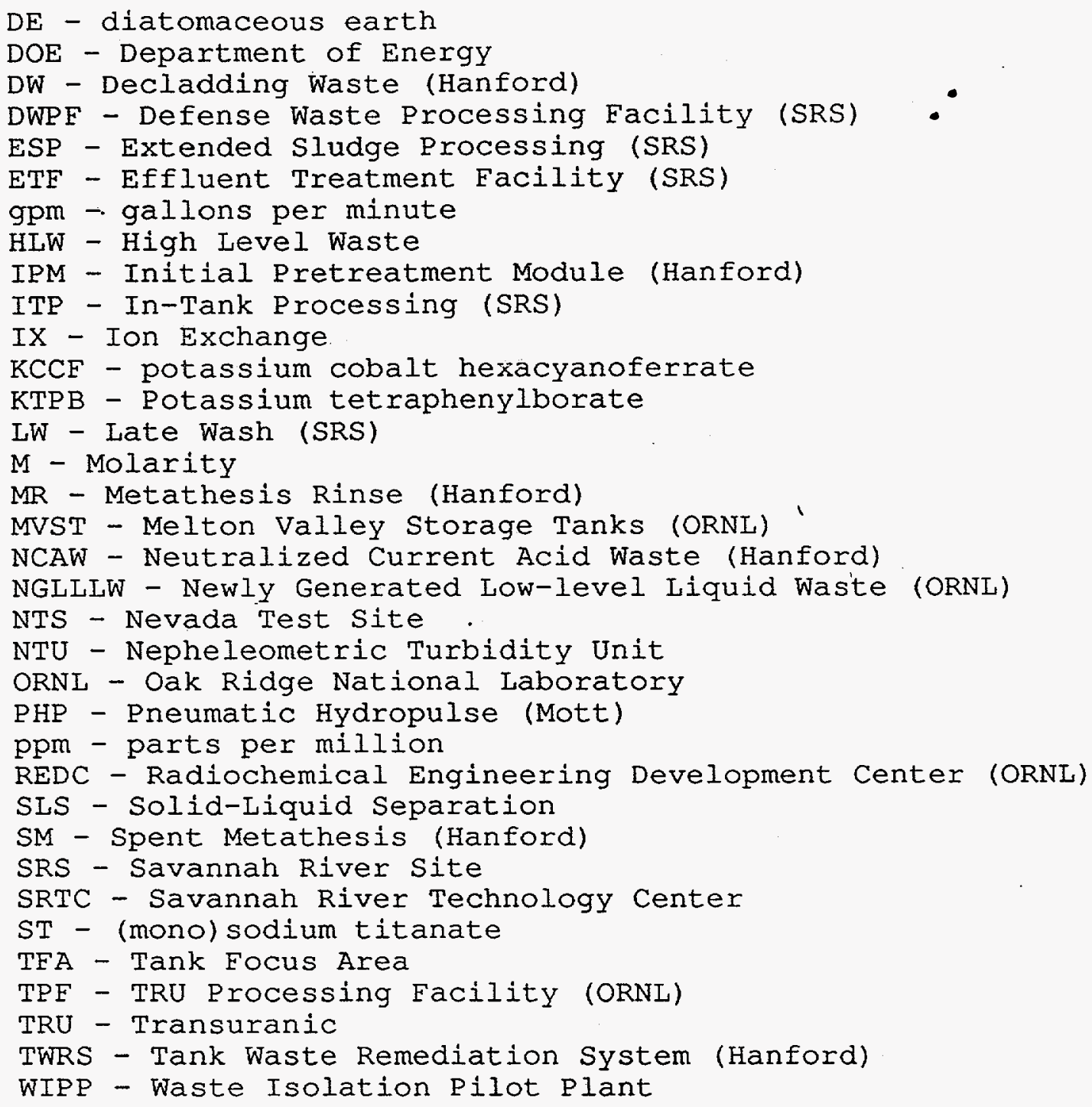


Introduction

The Tank Focus Area (TFA) of the Department of Energy (DOE) Office of Environmental Restoration and Waste Management (EM) addresses remediation of liquid waste currently stored in underground tanks. Several baseline technologies for treatment of tank waste can be categorized into three types of solid liquid separation: (a) removal of radioactive species that have been absorbed or precipitated, (b) pretreatment for ion exchange, and (c) volume reduction of sludge and wash water. The solids formed from precipitation or absorption of radioactive ions require separation from the liquid phase to permit treatment of the liquid as Low Level Waste. Prior to ion exchange of radioactive ions, removal of insoluble solids is needed to prevent bed fouling and downstream contamination. Volume reduction of washed sludge solids would reduce the tank space required for interim storage. The scope of this document is to evaluate the solid/liquid separations needed to permit treatment of tank wastes to accomplish these goals. The document summarizes previous alkaline waste testing, with an emphasis on crossflow filtration, to.obtain a general understanding of the behavior of radioactive wastes on available equipment. The document also provides general information about filtration and a path forward for testing.

Table 1

Estimated Tank Waste Inventory and Treatment

\begin{tabular}{llll} 
Waste & $\begin{array}{l}\text { Current } \\
\text { Inventory } \\
\text { (kgal) }\end{array}$ & $\begin{array}{l}\text { Treatment } \\
\text { Rate }^{a} \\
\text { (gpm) }\end{array}$ & $\begin{array}{c}\text { Project } \\
\text { Demo } \\
\text { Date }\end{array}$ \\
\hline SRS Sludge & 3500 & $1 \mathrm{c}$ & $12 / 81$ \\
SRS Salt/Sup.b & 30,000 & 14 & $1 / 83$ \\
West Valley Tank & 600 & 10 & 1984 \\
Hanford Tanks & $61,000^{\mathrm{d}}$ & $57^{\mathrm{e}}$ & $7 / 96$ \\
ORNL Gunite & 469 & $200-300^{\mathrm{f}}$ & $\sim 7 / 96$ \\
ORNL MVST-Cs & $350(25)^{\mathrm{g}}$ & 1 & $9 / 96$ \\
ORNL TPE & 100 & 5 & $\sim 9 / 96$ \\
ORNL REDC & $0(12)^{\mathrm{h}}$ & 0.05 & $\sim 3 / 97$ \\
ORNL NGLLLW & $0(120)^{\mathrm{h}}$ & 1 & $\mathrm{n} . \mathrm{a}$.
\end{tabular}

aestimated treatment facility flow rate during operation

bcombined saltcake and supernate volume

cExtended Sludge Processing (ESP) overall sludge washing rate

$\alpha_{\text {combined saltcake, supernate, and sludge volume }}$

eestimated average flow rate into the evaporator

festimated flow rate during sluicing operation

gquantity to be treated in 1996 demonstration

hestimated annual generation and treatment rate 
The estimated inventories of underground storage tanks at SRS, West Valley, Oak Ridge, and Hanford are listed in Table 1. These waste tanks represent the majority of the High Level Waste in the DOE complex that are scheduled for treatment demonstrations. The estimated treatment rates are based on average process design criteria or conceptual design criteria.

\section{General Information on Solid/Liquid Separation}

\section{Solid/Liquid Separation Methods Considered}

Solid/Iiquid separation (SLS) technologies considered for these applications can be placed into three primary categories:

Clarification:

Settling

Centrifugation

Hydrocyclone

Dead-end filtration:

Media (deep bed)

Disposable cartridge

Backwashable cartridge (polymeric)

Backwashable cartridge (metal)

Crossflow filtration:

Metal filters:

Sintered stainless steel powder

Stacked etched stainless steel disks

Ceramic/metal

Ceramic filters:

Alumina

Alumina/zirconia

Graphite/titania

Graphite/zirconia

Polymeric filters

\section{Cressflow Eiltration Equipment at Savannah River Site}

The solid/liquid separation techniques used in the Effluent Treatment Facility (ETF), In-Tank Precipitation (ITP), Extended Sludge Processing (ESP), and Late Wash (LW) facilities at SRS were researched for viability prior to construction. Testing was done at various locations and at differing scales for the facilities. Laboratory-scale equipment, approximately 1:750 scale, has been used by. Savannah River Technology Center (SRTC) for scoping 
activities with larger equipment used for engineering parameters and scale-up confirmation.

Scoping activities with lab-scale equipment are adequate for identifying significant impacts to filtration performance, although filtrate fluxes are generally higher than observed at production scale. Higher fluxes on small-scale equipment have been attributed to more effective backpulsing and chemical cleaning. In addition, end effects cause increased turbulence that impacts the boundary layer thickness. On short filter tubes the high turbulence area is a significant fraction of the length and thereby contributes to higher flux rates.

Although numerous crossflow filters are commercially available, few are adaptable to high radiation fields and concentrated caustic. Filters made of seamless, sintered stainless steel, such as those used in ITP at SRS, are completely welded to the housing and contain no polymeric components. Pore sizes for sintered stainless are as low as 0.2 microns (nominal). These metal filter elements are available from at least three vendors (i.e., Mott, Pall, and Graver Separation Systems). Woven or mesh fiber stainlesssteel filters are also available, but pore sizes are generally larger and tube walls thinner. Stacked etched disks made of stainless steel are available from one vendor, vacco. These filters have a tightly controlled pore size with a minimum pore dimension around 1 micron. The stacked etched disk filters can be made entirely of stainless steel. Excellent backpulse performance is expected from these filters since the pore is a straight channel, not a tortuous path as in sintered filters.

Asymmetric ceramic filters for liquid service are available from U.S. Filter and CeraMem. The ETF at SRS utilizes Ceraflo ${ }^{\mathrm{TM}}$ microfilters from U.S. Filter ( 0.2 micron) made. entirely of alpha-alumina. Smaller pore sizes are available, but gamma-alumina or zirconia is used as the membrane material. The gamma-alumina is less tolerant to high $\mathrm{pH}$ solutions than alpha-alumina. Ceramic filters typically have polymeric gaskets at the ends to seat them in a faceplate. The faceplate is then attached to a housing with a polymeric o-ring. In addition, the end of a ceramic filter is typically coated with a porcelain to prevent permeation into the porous support material.

Combination ceramic/stainless-steel filter tubes are also available commercially from Graver separation systems. The ceramic is composed of titania and is bonded to the stainless-steel substrate by sintering. A pore size of approximately 0.1 microns is reported by the vendor for these filters. The stainless-steel substrate can be welded to the housing, avoiding the use of any polymers in filter construction. 
Chemical resistance to high caustic environments and radiation tolerance would need to be established for the ceramic and ceramic/steel filters. Also, some forms of titania-related materials are capable of extracting soluble strontium and actinides from alkaline solutions. Examination of this extraction phenomenon would need to be completed on the ceramic/steel filters before they could be put into use.

Polymeric crossflow filters are available in a variety of pore sizes and materials of construction. The materials normally used for polymeric filters are generally not as resistant to chemical, abrasive, or radiolytic attack as inorganic filters. Testing at SRS, in support of the reverse osmosis membranes in the $\mathrm{ETF}$, was completed on the radiation tolerance of membranes. Three polyamide and polysulfone reverse osmosis membranes were exposed to $50 \mathrm{Mrad}$ of radiation from a Co-60 source with no degradation in membrane performance. ${ }^{2}$ Filters made of fluoropolymers are not expected to tolerate radiation as well as membranes of polyamide and polysulfone.

An inherent operational consideration in crossflow filtration is to identify the fate of the concentrate stream. Only a portion of the liquid is removed as filtrate in a single pass through a crossflow filter. The concentrate can be sent on to another filter, as in the ETF at SRS, or returned to the feed tank, as in the ITP process at SRS. In the ETE, the feed stream is very low in insoluble solids and the concentrate is passed to a second and third stage. At the end of the third stage concentrate is removed at a rate of a few percent of the inlet flow rate, over $95 \%$ of the water is removed as filtrate. In the ITP process, $10 \%$ or less of the water is removed in a single pass and the concentrate is returned to the 1.2 million gallon feed tank. Alternatively, many commercial operations are completed in batch mode where a small auxiliary tank is used to concentrate (and wash, if necessary) the solids.

While crossflow filtration is generally applicable, for some waste streams disposable cartridge filters may be appropriate. The general problem with disposable cartridge filters is the high radiation dose associated with spent filters, as well as creation of a secondary waste stream. Several filters are available that are backwashable cartridges. This option would permit reduced radiation doses by backwashing. most of the solids off the filter cartridge prior to disposal. The filter can be reused in numerous cycles until the backwashing cycle is too frequent and the filter must be replaced. It is anticipated that the permanent fouling is due to a small amount of fines. The cake could be discharged back to the tank, and the filter would then contain relatively small amounts of activity. 
Chemical cleaning with dilute acids may be needed. to reduce the radiation level for disposal. This type of filter may be useful, for example, in the MVST Supernate Cesium Removal demonstration.

\section{Effect of Scale}

Small-scale filtration tests can be accomplished on all of these waste streams. Screening tests to identify the most practical solid/liquid separation technology can be done on the laboratory scale $(0.1 \%$ to $0.5 \%$ of full-scale filtrate flow rate). From these screening tests, approximate filtration rates and operating parameters can be determined. Decontamination factors (DF) can, in some cases, be determined from screening tests also. The DF of a freshlyprecipitated material can be determined, but not that of an aged slurry which may have colloidal or complexed radioactive ions. Solids removal efficiency (i.e., clarity of the filtrate) can be determined as long as the, simulant has a similar particle size as the waste.

Scaling parameters and more accurate flow characteristics can be obtained from bench-scale test units $10.5 \%$ to $2 \%$ of fullscale filtrate flow rates). An intermediate scale test unit is generally needed to appropriately size a demonstration unit. For crossflow filters, end effects will be reduced with longer filter tubes. Filter tube length, or number of tubes in series, can also impact the filter performance because the last tube has lower velocity and pressures. Edge effects with media filters, similar to those seen with ion exchange beds, are reduced on a larger scale unit.

Pilot-scale tests (5\% to $10 \%$ of full-scale filtrate flow rates) are generally needed to verify filter performance and hydraulic effects. Backpulsing effectiveness with rigid filters is an important parameter that can only be accurately demonstrated on the pilot scale.

The filtrate production rate and waste feed batch size are related, and must be considered when designing tests and test equipment. The smaller the amount of insoluble solids present in the waste, the larger the batch size needs to be to ensure that enough "foulant" is present to achieve steady state behavior. An estimate of the batch size for wastes with low insoluble solids content $(<0.1 \mathrm{~g} / \mathrm{L})$ is $>100$ gallons/ft ${ }^{2}$. With high insoluble solids content feed ( 5 wt o), smaller amounts are adequate $\left(\sim 10 \mathrm{gal} / \mathrm{ft}^{2}\right)$. These guidelines will vary, depending on the particle size and filter pore size, but can be used as a first approximation. The size of the unit and feed tank should be appropriately scaled so that steady-state performance is achieved. Ideally, enough solution should be used to represent one full cycle of the unit operation (i.e., time between chemical 
cleanings for a filter) in a single-pass mode. This is often not practical for routine investigations, but should be done at least once to verify performance.

Further information on the effect of scale will be obtained when the SRS ITP facility begins radioactive operations. Comparison tests are being planned and documentation will be available at that time.

Facility status

\section{SRS Process Status}

The Effluent Treatment Facility treats low-level aqueous waste prior to release through a permitted outfall (Figure 1). The low-level waste originates from several sources, but is predominantly condensed evaporator overheads and storm water runoff (Table 2). The facility removes both radioactive and hazardous components using, crossflow filtration, ion exchange, carbon absorption, evaporation, and reverse osmosis. The concentrated waste is disposed in the Saltstone facility. The ETF replaced the onsite seepage basins for disposal of this waste stream and has been in operation since 1988 .

The Savannah River Site High-level Waste treatment flowsheet 3 (Figure 2) includes (a) the Extended Sludge Process (ESP), and (b) In-Tank Precipitation (ITP). The ESP includes intank washing and settling of sludge, followed by decantation of the washwater. The washwater may be either evaporated or used for salt dissolution for ITP. The ITP involves precipitation of cesium with tetraphenylborate ion and sorption of strontium and actinides on monosodium titanate from supernate and redissolved salt cake. The precipitation and absorption are followed by separation of the insoluble solids with crossflow filtration. Tank waste volumes, flow rates, and the date of project demonstration are listed in Table 1 .

In the ITP process, a 1 wt $\%$ slurry of tetraphenylborate and monosodium titanate in salt solution is concentrated to $10 \mathrm{wt}$ o using the crossflow metal filter (Table 3). In the nominal flowsheet, a second and third batch of salt solution are added, and each is precipitated and concentrated. The three batches of 10 wt $\%$ slurry are then washed by continuous addition of water to the feed tank and removal of washwater using crossflow filtration. The washed insoluble solids are then transferred to a tank for interim storage.

The sludge from ESP and insoluble solids from ITP are processed in the Defense Waste Processing Facility (DWPF) and vitrified in borosilicate glass (Table'4). The decontaminated aqueous effluents from all processes are 
disposed in Saltstone. The ESP process was initiated approximately one year ago. The ITP facility has been constructed, has undergone facility testing, and is currently readying for radioactive operations.

The DWPE includes washing of the cesium tetraphenylborate precipitate/monosodium titanate slurry to remove ritrite ion in the Late Wash (LW) process. The $L W$ process utilizes a crossflow filter identical to the ITP filter to accomplish the washing. The LW facility is currently under construction.

West Valley PUREX Sludge Treatment Process

The West Valley Supernate Treatment System utilizes a crossflow Mott filter as a polishing filter prior to ion exchange treatment. 4 The process involves sludge washing and settling prior to filtration and ion exchange. The washing procedure has been completed twice using this equipment. The sludge settles in the tank and the pump utilizes a floating suction to remove only the clarified liquid. The filtrate is cooled and passed through four zeolite ion exchange resin beds. A sand filter is used after the four columns to remove any zeolite fines. The prefilter is a vertically-oriented Mott HyPulse sintered metal filter with a 0.45 micron pore size. The 20 elements are 10 feet long with internal diameters of 0.6 inches giving a collective surface area of $74 \mathrm{ft}^{2}$. The normal operation utilizes a $30 \mathrm{gpm}$ concentrate stream, which returns to the tank, and a $10 \mathrm{gpm}$ filtrate flow rate $\left(0.14 \mathrm{gpm} / \mathrm{ft}^{2}\right)$ at $10 \mathrm{psi}$ differential pressure. The design criteria for insoluble solids content was 200 ppm. Settling rates for this sludge are very fast, with $95 \%$ of sludge settling in 1.5 hours.

\section{Hanford Status}

The Hanford tank waste (Table 5) is composed of a variety of wastes from nuclear fuel processes such as bismuth phosphate, uranium recovery, Purex, Redox, and others. The wastes are composed of varying quantities of sludge (metal hydroxides and oxides), salt cake, and supernate (concentrated salt solutions). The goal for Hanford support work is to identify the solid/liquid separation process type and approximate size to include in the Initial pretreatment Module (IPM) conceptual design by February 1996. Testing on radioactive waste is planned for July 1996.

The Tank Waste Remediation System (TWRS) Pretreatment flowsheet for treatment of Hanford high-level tank waste specifies locations for SLS processes ${ }^{5}$ although the baseline is currently being modified. The SLS processes are not yet finalized but baseline methods are referenced. If alternate SLS methods are to be used, they must be identified before 
the conceptual design is*finalized. Acceptance criteria for the SLS effluent have not yet been established, although it is estimated at $50 \mathrm{ppm}$ of insoluble solids. ${ }^{6}$ The final criteria for influent to the ion exchange unit (SLS effluent) will impact the SLS requirements.

Three SLS needs have been identified in a proposed modification of the Initial Pretreatment Module for highlevel tank waste at Hanford (Eigure 3).6 The flowsheet involves separation of insoluble solids both to prevent blinding of ion exchange columns and to reduce radioactivity in the aqueous supernate stream. Some portion of the radioactive species present in the waste is insoluble and can be removed by filtration. The radioactive cesium is not separable by filtration and will be removed by ion exchange. Destruction of organics may be required prior to further treatment. Other radionuclides ( $\mathrm{Sr}$ and $\mathrm{TC}$ ) may also need to be removed by ion exchange or sorption. The radionuclides are to be eluted from the resin(s) and mixed with the high activity sludge to form a glass waste. The decontaminated salt solutions will also be solidified, probably in a lowlevel waste glass matrix.

\section{Sludge Leaching and washing}

The first Hanford SLS need occurs during sludge leaching and washing. Although the current flowsheet specifies an in-tank settle and decant step, this may not be sufficient to achieve the solids loading necessary. ( 20 wt $\%)$, may produce excessive amounts of washwater, and may be prohibitively expensive. If out-of-tank SLS processes are necessary, centrifugation, filtration, or another SLS method would be needed to concentrate and wash the insoluble solids. If this primary separation does not sufficiently clarify the aqueous phase, a polishing filter to further remove unsettled insoluble solids before evaporation may be needed.

\section{Ion Exchange Influent Polishing}

The second Hanford SLS need is for a polishing filter to remove precipitated solids from the salt solution evaporator bottoms to prevent ion exchange column blinding. The current TWRS flowsheet specifies a deep bed glass frit filtration system for this process module.

\section{Ion Exchange Effluent Fines Removal}

The third Hanford SLS need is to catch ion exchange resin fines. Ion exchange resins used for radionuclide removal degrade in the highly caustic supernate and high radiation field. Eines from decomposing resins will contain radioactive isotopes that can contaminate downstream processes to unacceptable levels. This SLS process is not 
included in the current baseline TWRS flowsheet, but has been included in the proposed modification.

\section{ORNI Status}

The ORNL process currently treats Low-level Liquid Waste by evaporation and storing the concentrate in Melton jralley Storage Tanks. The numerous Gunite Tanks are no longer used for storage of waste but do contain residual amounts of sludge. The liquid waste originates in several facilities, but the majority of the radionuclides originate in the Radiochemical Engineering Development Center.

The ORNL Gunite tanks contain heels of thick sludge which will be sluiced and transferred to the MVST (Table 6). The sluicing will be done with water and perhaps a suspension agent. Reconcentrating the sluiced slurry would permit reuse of the water, minimizing water usage. Tentative plans are to allow the material to settle in an intermediate tank. If settling is not very fast, filtration may be needed. The ORNL Gunite tank demonstration is tentatively scheduled for a test on radioactive waste in mid 1996, and commence full operation in mid 1997.

The MVST contain both sludge and aqueous supernate from various processes (Table 7). A portion of the supernate will be used to mobilize the sludge. The sludge will be separated from the aqueous supernate and solidified in the Transuranic (TRU) Processing Facility (TPF). The sludge dewatering technique and solidification process are being evaluated. The current baseline treatment is centrifugation, 7 although this has not been tested. Treatment requirements need to be further defined to fully evaluate the appropriate SIS technique.

To provide needed space in the MVST, some of the aqueous supernate is removed and solidified. A pretreatment process for solidification of this waste stream is under study (Table 8). Pretreatment may be needed because the current practice of solidification is expected to be inadequate due to anticipated increases in cesium activity. The MVST Cesium Removal process under investigation involves $\mathrm{pH}$ adjustment, filtration, cesium removal by ion exchange, and subsequent solidification of the effluent. The current plan is to $\mathrm{pH}$ adjust the supernate, settle the bulk of the insoluble solids within the MVST, and remove residual unsettled insoluble solids with cartridge filtration. This filtration is necessary only as a guard to prevent ion exchange column blinding. The ORNL MVST Cesium Removal Demonstration Project is expected to operate on 25,000 gallons of radioactive waste in late 1996. The demonstration facility will be turned over for routine operations at completion of the demonstration. 
Source treatment of waste generated by the Radiochemical Engineering Development Center is also planned (Figure 4). The majority of the radionuclides in the Low-level Iiquid Waste stream originate in this REDC waste stream (Table 9). The REDC waste contains only small amounts of insoluble solids ( 0.2 wt $\left.\frac{\circ}{0}\right)$ which will be concentrated. The aqueous waste will be treated with ion exchange to remove cesium. The partially-decontaminated REDC effluent would then be processed either in the current central waste treatment system or in the NGLLLW facility. The ORNL REDC process is to commence operations in early 1997. The facility will treat approximately 10,000 gallons of waste per year. Detailed design of the equipment, to be installed in a shielded cell is due at the end of FY95.

Space in the MVST is very limited and an alternate disposal method is needed. A new flowsheet has been proposed for Newly Generated Low Level Liquid Waste that permits segregation and solidification of radionuclides followed by solidification of the decontaminated waste (Table 10). The aqueous supernate waste currently stored in the MVST may also be treated in this facility. Development of the ORNL NGLLLW treatment process is not yet an approved project. Current plans are to solidify supernate liquids in grout for disposal at the Nevada Test Site (NTS) and solidify sludges for disposal the Waste Isolation Pilot Plant (WIPP). The sludge solidification method has not yet been determined. The NGLILW process provides an alternative for grouting of supernates if NTS disposal is not permitted and provides centralized treatment of waste from future programs.

The proposed flowsheet for NGLLLW involves precipitation of radioactive strontium by addition of non-radioactive strontium (Eigure 5). 8 The strontium precipitates, probably as the carbonate salt, and is filtered. A method for ruthenium removal may be required, but has not yet been defined. The filtrate is $\mathrm{pH}$-adjusted and treated with potassium cobalt hexacyanoferrate to precipitate or sorb radioactive cesium, which is then filtered. To obtain an adequate cesium decontamination, a second addition of potassium cobalt hexacyanoferrate (KCCF) and filtration is then completed. The radionuclides will be combined and solidified in one process, and the decontaminated aqueous waste solidified in another.

\section{Filtration Processes}

Although many SLS techniques are commercially available (i.e. centrifuges, clarifiers, depth filters, drum filters, etc.), crossflow filtration has several advantages over other techniques: 
1. Minimal maintenance requirements simplifies use in high radiation fields (vs. centrifuges)

2. Generally does not require additives such as

diatomaceous earth (DE) which add waste volume and may

change waste chemistry (vs. dead-end filters)

3. Generally does not require additives such as

polymeric flocculating agents that can change the

process chemistry (vs. depth filters)

4. Can be used to rapidly concentrate slurries to high

weight percent insoluble solids (vs. settling or clarifiers)

5. Can be used to continuously wash slurries, reducing washwater volumes (vs. settling or clarifiers).

6. Space requirements are generally less than most other SLS techniques.

As opposed to crossflow, "dead-end" filtration is a commonlyused technique. ${ }^{9}$ Dead-end filtration is conventional

filtration where the slurry passes through, a filter and solid cake collects on the surface. This technique is applicable to waste streams with low quantities of suspended solids that have large particle sizes. Dead-end filtration is not suitable for very fine suspensions because of a rapid increase in the pressure drop associated with the filter cake. Rapid fouling is usually alleviated by introduction of a filter aid such as DE or a flocculating agent. The DE provides a porous cake and acts as an absorbent for the fine particulates; the flocculating agent combines fine

particulates to form larger aggregates which are easier to filter. Both of these additives have the undesirable side effect of adding waste volume and may change the process chemistry. The DE may dissolve or disintegrate to gels in caustic solutions $(\mathrm{pH}>11)$, potentially causing downstream fouling. The flocculating agents are usually organic polymers, which will decompose under high radiation fields. Although this is an appropriate treatment mode for many waste streams, if crossflow filtration can be shown effective, introduction of these additives to the waste stream can be avoided.

Dead-end filtration is also not appropriate for high concentrations of insoluble solids. For thick slurries, settling in a clarifier followed by dead-end or multimedia filtration is often done. The predominant drawback of multimedia filtration is the large backwash volumes that are needed to clean the solids from the filter media. Flocculating agents are also normally added prior to clarification and filtration.

Bench-scale and pilot-scale testing using radioactive waste is normally required for final filter selection. Bench-scale testing on simulated wastes can be used to screen several 
types of filters. Pilot-scale testing is used to.obtain engineering parameters and long-term fouling effects.

Operating parameters needed for conceptual design input for crossflow filters are typically:

1. Flux (filtrate flow rate per unit surface area)

2. Differential pressure (range of transmembrane pressures)

3. Crossflow velocity (axial flow rate)

4. Backpulse frequency (if applicable)

5. Backpulse duration (if applicable)

6. Filtrate quality (decontamination factor)

7. Cleaning method (chemical needed, concentration, duration, temperature)

Backpulsing, a brief, vigorous reversal of filtrate flow, is typically used only with rigid filters constructed of ceramic or metal. A cartridge filter is available from Pall corp. with a rigid polymer sleeve that permits bąckflushing. Also, a semi-rigid steel filter is available from Microfiltrex and AEA Ltd. utilizing an electrical pulse to generate gas bubbles on the filter surface.

Flux rate data are typically expressed as a function of the concentration of insoluble solids and will generally decrease as solids content rises. Intrinsic to these measurements is viscosity and yield stress data when dealing with high weight percent solids slurries ( $>1$ wt $\%)$. Flux data is also expressed as a function of time, $i . e$. the rate of filter fouling. In an appropriately designed microfiltration unit, flux may decrease quickly for a short time, but then remain stable for long periods. When applicable, the necessary frequency and pressures of backpulsing are also determined. The required pore size is determined from both the downstream solids limit and the optimum flow rate (a smaller pore size filter may give a higher flux). All of these data together help determine the optimum filter type, pore size, and pumping requirements for the application.

The fate of chemical cleaning solutions must also be considered in flowsheet development. Cleaning solutions will typically contain insoluble solids that are partially composed of radioactive isotopes. Acidic cleaning solutions can also solubilize radioactive isotopes which are normally not soluble in the alkaline sludges.

Solid/liquid separation methods are influenced by the colloid chemistry of the insoluble solids. The colloid chemistry of sludge encompasses several key areas of interest for solid/liquid separation: settling, absorption, coprecipitation, and rheology. Settling characteristics impact the feasibility of clarification, centrifugation, and pumping. Studying the colloid chemistry of sludges is 
important to predicting änd controlling solid/liquid separation processes.

\section{Elowsheet Considerations}

\section{Hanford Considerations}

A significant complexity for the Hanford flowsheet is simulant development. Simulants can be used to complete cursory examination of filter types and to bracket operating conditions. Preparation of simulants for the different wastes is needed. Unlike freshly precipitated solids in ITP and NGLLLW, the insoluble solids in Hanford waste were formed years ago and have aged, making simulant development more challenging: Depending on the finalized flowsheet, consideration of chemical kinetics is also important. For example, after concentration of supernate by evaporation and prior to polishing filtration, sufficient time for cooling and precipitation to occur is needed. If sufficient time is not allowed, post-precipitation can occur that could cause ion exchange bed fouling. Similarly, dilution of supernate prior to polishing filtration can also cause postprecipitation.

\section{QRNI Considerations}

For the ORNL wastes, a significant flowsheet consideration for the NGLLLW is carbon dioxide degassing in the second filtration stage. Neutralization of the caustic solution in the second unit operation will form carbon dioxide. Depending on conditions, release of carbon dioxide could occur as the pressure drops as the liquid passes through a filter membrane, causing gas blinding.

Chemical cleaning of filters fouled with KCCF precipitates may not be feasible without chemical decomposition of KCCF. The chemical decomposition of KCCF may form hazardous components, such as cyanide, 10 which must be controlled. Chemical cleaning of KCCF precipitate from the filters will generate a new waste stream that contains those hazardous ingredients and radioactive cesium from decomposed $\mathrm{KCCF}$. This waste stream must be disposed in a final waste form.

\section{SITE TESTING}

\section{SRS Effluent Treatment Eacility Tests}

The ETF utilizes a crossflow microfilter $(0.2$ micron) constructed entirely of alpha-alumina. Other technologies which were tested or considered ${ }^{2}$ were: tubular precoat (DE), multi-media (sand/anthracite), and ultrafiltration (precoated sintered metal). After startup of the facility using the 
ceramic filters, severe filter fouling was observed, and a program was initiated to investigate other filter types. Filters tested on simulants in the alternative study ${ }^{11}$ were (in descending order of effectiveness): centrifugal ultrafilter, tubular ultrafilter, deep bed filter, backwashable cartridge, stainless steel mesh, poroús metal, tubular fabric, centrifuge, and electrocoagulation/filtration.

Concurrent with the alternative filter studies, investigations into causes of fouling were conducted. The investigations revealed that bacteria were largely responsible for fouling and the primary source of bacteria was treated and diverted.12 Measures were also taken to mitigate the impact of bacteria from other sources, particularly surface water. ${ }^{13}$ These changes were sufficient to avoid implementation of alternative filtration and the facility capacity has been adequate for over four years. The facility has operated at approximately 75\%, of design capacity, but the quantity of wastewater from the site has also decreased.

The backpulse system for the ETF filters was upgraded after startup to increase the velocity and pressure of the pulse. A high pressure filtrate line was recirculated back to the filters to permit an air-free backpulse. Introduction of air to the filters during the backpulse is known to cause air blinding. The three filter skids were also sequenced so that the pulse was not done at the same time, which reduced the effective transmembrane pressure.

A $1 / 40$ th scale ceramic filter was also built in the ETF and demonstrated on radioactive waste. ${ }^{14}$ The pilot-scale filter operated on a slip-stream from the full-scale filter so that scaling factors were obtained. This filter correlated relatively well with the full-scale filter on the radioactive waste samples.

\section{colloid Chemistry Studies with SRS Sludge}

Studies are underway to examine the colloid chemistry of sludges at both Hanford and ORNI. At SRS, the chemistry of the sludge has been examined, 15 and full-scale sludge washing is underway. In laboratory studies, unwashed sludge from SRS Tank $42 \mathrm{H}$ initially contained 23 wt $\frac{\circ}{6}$ insoluble solids and 6.5 wt $\%$ soluble solids. Four wash and settling cycles were conducted using approximately equal volumes of sludge sample and inhibited wash water. The rate of settling was observed to increase with each washing, consistent with reduction in the density and viscosity of the aqueous phase. In each of the four washing cycles, the solids settled to 20 to 22 wt within 14 to 18 days. The final soluble sodium content was $0.1 \mathrm{M}$. The volume of sludge after each washing was about 
$120 \%$ of the initial unwashed sludge volume (i.e., an expansion of the sludge occurred as a result of the first wash, but did not increase further). There was a significant amount of insoluble sodium ( 3.9 wt $\frac{\%}{\circ}$ ) and cesium associated with the sludge after four washes. Some uranium and plutonium was observed to not settle with gravity but did settle during centrifugation, suggesting the presence of colloids. The centrifuged supernate from the first wash contained $0.057 \mathrm{ppm}$ of uranium and $0.00010 \mathrm{ppm}$ of plutonium. The gravity settled supernate from the first wash contained $1.42 \mathrm{ppm}$ of uranium and $0.0026 \mathrm{ppm}$ of plutonium. Insoluble solids content of the supernate and decanted wash water was not directly measured due to the observed clarity of all samples and sharp interface between supernate and sludge. The analysis of iron, the predominant component in sludge, strongly suggests that sludge was not present in the supernate or decanted wash water as all results of gravity settled samples were $<0.12 \mathrm{ppm}$ of iron.

Aluminum dissolution will be done on severál sludge tanks at SRS to reduce the amount of aluminum in the sludge and final glass wasteform. 16 The procedure involves addition of sodium hydroxide (minimum of $3 \mathrm{M}$ plus 3 equivalents of hydroxide per aluminum ion), heating to $85^{\circ} \mathrm{C}$ with steam, and mixing for 3 days. Only the gibbsite form of alumina is reported to readily dissolve under these conditions. The remaining sludge settles to approximately $20 \mathrm{wt} \%$, and the supernate is decanted. The sludge is then washed with inhibited water. Experiments indicated that aluminum dissolution with simulated sludge was comparable to radioactive waste.

At SRS, the wash water may be concentrated in an evaporator to increase the salt content prior to treatment in the ITP facility. Alternatively, the wash water may be used for salt cake dissolution for influent to the ITP facility. The washed sludge is pumped to the Defense Waste Processing Facility where it is vitrified into a glass waste form. The liquid decontaminated in ITP is disposed in saltstone.

\section{SRS In-Tank Precipitation Tests}

Testing for the In-Tank Precipitation facility at SRS was conducted on several different scales.17-20 The primary testing has been completed using (scale to current ITP):

"High-level Caves" filter (1/1000)

Experimental Laboratory filter (i/750)

Precipitation Test Facility (1/6)

In-tank Demonstration $(1 / 1 *)$

* series configuration of four filter tube bundles

In addition, the ITP facility has been' tested with simulated waste. Radioactive waste has been tested on the "High Level 
Caves" filter and the In-Tank Demonstration. All other testing was done with simulated wastes.

Both the High Level Caves and the In-tank Demonstration filters were tested with simulated waste prior to radioactive waste. Filter performance for both filters was similar for simulated and radioactive waste at 1 wt $\%$

The obtainable decontamination factor was determined using radioactive waste with the "High Level Caves" filter and confirmed with the In-Tank Demonstration. Pore sizes of 0.2 , 0.5 , and 2.0 microns were initially examined. The 0.5 micron. pore size gave an adequate decontamination factor and had a higher flow rate than the 0.2 micron filter.

The optimum performance parameters were determined using simulated waste. The optimum flux was obtained with a crossflow velocity of 3 to $3.5 \mathrm{ft} / \mathrm{s}$ and backpulse frequency of five minutes. The pump type was a significant factor in filter performance, with a low-shear design such as diaphragm pumps yielding the best results.

At 1 wt $\%$ insoluble solids, the various filter units gave similar performance data $\left(0.23-0.3 \mathrm{gpm} / \mathrm{ft}^{2}\right)$. The exception was the In-Tank Demonstration filter which had a flux of $\left(\sim 0.11 \mathrm{gpm} / \mathrm{ft}^{2}\right)$ approximately $40 \%$ of the other filters when using 1 wt $\frac{\circ}{0}$ slurry. 21 This was attributed to the different configuration of the filters. 22 The In-Tank Demonstration filter had four $10 \mathrm{ft}$ long filter tube bundles in series with each tube bundle approximately $50 \mathrm{ft}^{2}$ of surface area. The first tube bundle had a much higher flux $\left(0.36 \mathrm{gpm} / \mathrm{ft}^{2}\right)$, indicating that the lower differential pressure and more concentrated slurry in successive bundles lead to lower flux. 22 The current ITP filter has one $10 \mathrm{ft}$ long bundle with $216 \mathrm{ft}^{2}$ of surface area.

Chemical cleaning of filters is accomplished with oxalic acid. This method has been effective at cleaning filters fouled with tetraphenylborate precipitate, sodium titanate, and simulated sludge solids. The sequence, volumes, durations, and conditions of chemicals and flush water are important parameters which must be considered in filter system design. Fate of the chemical cleaning solutions and the concentration of radioactive isotopes in the cleaning solutions are important in flowsheet development. The ITP cleaning solutions are returned to the 1.2 million gallon feed tank.

As a result of observations during the ITP filter acceptance testing, the backpulse system was upgraded significantly. Due to the difficulties of remote maintenance, the backpulse system is outside of the shielded cell, increasing the length of pipe between the backpulse chamber and the filter shell. 
Changes made to improve the system included: installation of fast acting valves in the backpulse line, reconfiguring the backpulse chamber so that a charge of gas is available for the backpulse, removing restrictions from the liquid and gas piping, and routing filtrate from the filtrate tank to the backpulse chamber to permit repeated backpulses.

The impact of simulated sludge and sodium titanate on the filter flux of tetraphenylborate slurries has been studied.23 At low concentrations $\left(<0.1\right.$ wt $\left.\frac{\circ}{6}\right)$, both materials impacted filter performance to a similar degree, however, the effect was not additive when both were included.

SRS Late Wash Tests

The feasibility of using Mott filters to wash simulated Late Wash precipitate was demonstrated on the laboratory scale.24 The influent for $L W$ is the washed product from ITP after up to two years' storage. The simulated slurfy is typically 10 wt $\%$ insoluble solids (Potassium tetraphenylborate and sodium titanate) and is irradiated using a co-60 gamma source to a projected average dose. Organic decomposition products from radiolysis are formed which impact filter performance and cleaning effectiveness.

The simulated Late wash cycle was investigated by addition of water to the slurry at the same rate as filtrate production. The water also contained small amounts of sodium tetraphenylborate to prevent dissolution of the cesium tetraphenylborate. Removal of nitrite ion compared well with the calculated rate based on dilution. Subsequent testing has focused on filtrate production rate optimization and chemical cleaning.25,26 Nitrite removal has also been demonstrated several times under various conditions.

West Valley PUREX Sludge Treatment Process

The Mott filter at West Valley has been very effective and has never been chemically cleaned during 11 years of operation. 4 Backpulsing has only been needed on rare occasions when the clarified liquid layer is low and the pump suction is near the sludge layer. Data is available on solids loading and particle size analysis only on samples collected prior to startup of the filter. The insoluble solids concentration in the supernate sample was $84 \mathrm{ppm}$, and had a particle size ranging from 0.1 to 3.0 microns. The particles in the sludge samples were all larger than 3 microns. The total dissolved solids are approximately 3 wt $\frac{0}{0}$. 


\section{Hanford Redox/Purex Sludge Tests}

Gravity thickening, centrifugation, air flotation, and crosisflow filtration were tested on simulated Redox and Purex sludges at Hanford.27 Gravity thickening was effective at concentrating the sludge and clarifying the supernate with a minimum of $550 \mathrm{ppm}$ of a polyelectrolyte added. The supernate contained less than $100 \mathrm{ppm}$ of suspended solids, and the concentrated sludge content of a full-scale system was estimated at $>10$ wt $\%$ (initial $\sim 6$ wt $\%$ ). Two bowl centrifuges, a Sharples P600. and a Bird horizontal bowl, were effective at removing over 99\% of suspended solids with approximately $200 \mathrm{ppm}$ of polyelectrolyte added. The sludges were concentrated to 16 to 20 wt $\%$ with the centrifuges. Polishing filters were recommended to further reduce the suspended solids in the centrate. An imperforate basket centrifuge was tested on synthetic sludge. Addition of polyelectrolyte to the imperforate basket centrifuge influent had little effect on centrate quality which contained approximately $100 \mathrm{ppm}$ of suspended solids. The flow rates through the bowl centrifuges was much higher than through the imperforate basket centrifuge.

The separation efficiencies of a 0.5 micron Mott Inertial (crossflow) filter was tested and found to produce filtrate with "virtually no solids".27 The simulated sludges were initially at $\sim 6$ wt $\frac{0}{6}$ suspended solids. It was demonstrated that the simulated Redox sludge could be concentrated to 15.5 wt $\frac{\circ}{0}$ solids and the simulated Purex sludge to 10 wt $\%$ solids. Filtrate flow rate was approximately $0.22 \mathrm{gpm} / \mathrm{ft}^{2}$ for Purex sludge and $0.13 \mathrm{gpm} / \mathrm{ft}^{2}$ for Redox sludge (differential. pressure was not reported). The sludge was washed by periodic addition of water to the feed tank. This method proved effective at soluble salt removal. The filter was also operated for 120 hours and only a slight decrease in filtrate flow rate was observed.

Dissolved air flotation and induced air flotation were found to be ineffective for solid/liquid separation of simulated Redox and Purex sludges. 27 Addition of polymers as flotation aids did not improve performance of either air flotation methods.

\section{Hanford Cladding Removal Waste Tests}

Tests were conducted using four solid/liquid separation technologies on simulated radioactive cladding removal wastes from the Zirflex process: centrifugation, sedimentation, crossflow filtration, and a back-flushable Mott inverted Pneumatic Hydropulse (PHP) filtration.28 (inverted Pneumatic Hydropulse refers to dead-end filtration from tube side to shell side.) The crossflow filter was determined to be the best option overall. The tests were conducted using a 
simulated non-radioactive waste as well as a uranium-spiked simulated waste. Three different $\mathrm{zirflex}$ stream simulants were tested: Decladding Waste (DW), Spent Metathesis (SM), and Metathesis Rinse (MR).

The inverted Pneumatic Hydropulse filter $(0.5 \mathrm{micron})$ was operated on simulated DW at 45 to $50^{\circ} \mathrm{C}$ with a feede flow rate of $0.22 \mathrm{gpm} / \mathrm{ft}^{2}$ The DW contained $1000-2100 \mathrm{ppm}$ of solids with a mean particle size of 1.2 microns. The maximum differential pressure (27 psi) was reached in 30 minutes in the first cycle and after 15 minutes in the seventh cycle, indicating rapid fouling. The filtrate turbidity samples were all less than 1 NTU.

Simulated SM contained 700-1000 ppm of solids that fouled the inverted PHP filter within three minutes and before a single filtrate sample could be collected. The simulated MR solution filtered at a rate of $0.22 \mathrm{gpm} / \mathrm{ft}^{2}$, with transmembrane pressure reaching 20 psi after 50 to 70 minutes.

Several different scales of crossflow filters were tested: a single 18 inch long, 0.25 inch internal diameter element; eight of these elements in series, and a seven-tube bundle with seven 5 foot long, 0.25 inch internal-diameter elements.

Filtrate from the non-spiked DW simulant on the Mott crossflow element was less than 0.5 NTU. The non-spiked DW filtrate flux was $0.10 \mathrm{gpm} / \mathrm{ft}^{2}$ at a crossflow velocity of 12 fps and a backpulse frequency of 5 minutes. The non-spiked SM was run at "room temperature" and yielded a flux of 0.1 $\mathrm{gpm} / \mathrm{ft}^{2}$ but had poor filtrate quality (175-500 ppm solids). The uranium-spiked DW flowrate was $0.18-0.26 \mathrm{gpm} / \mathrm{ft}^{2}$ at a crossflow velocity of 14 fps and backpulse frequency of 5 minutes. The differential pressures were not specifically reported, but were listed as 15 to $>45 \mathrm{psi}$. The seven-tube bundle had high fluxes on non-spiked DW, with a 32-hour run operating at $0.18 \mathrm{gpm} / \mathrm{ft}^{2}$ at $35 \mathrm{psi}$ feed pressure and $5 \mathrm{fps}$ crossflow velocity. No reason was suggested for the higher flow rate on the bundle versus single tubes.

Hanford Neutralized Current Acid Waste Tests

\section{Simulated Waste}

Testing was conducted on simulated Neutralized Current Acid Waste (NCAW) waste at the Chemical Engineering Laboratory using a centrifuge, crossflow filter, Mott Pneumatic

Hydropulse Filter, and by settling and decanting. 29 The mean particle size of the synthetic sludge fed to the centrifuge was reported to be 1 to 1.5 microns. A solid bowl centrifuge yielded moderate efficiencies with $\sim 60$ vol $\frac{\circ}{0}$ solids removal after optimization. Addition of polymeric flocculating 
agents to the feed did not significantly improve centrifuge performance.

Mott crossflow filters were tested as polishing filters on the centrate from a mixture of wash water and sludge. A second centrifugation of the mixture was necessary to prevent rapid filter plugging. The crossflow filters were observed to produce poor filtrate clarity $(\sim 460$ NTU) with both 0.5 and 0.2 micron filters. The flux rate was 0.13 to $0.22 \mathrm{gpm} / \mathrm{ft}^{2}$ for the 0.5 micron filter and centrifugal pump, and were about 20\% lower for the 0.2 micron filter (differential pressure $=25 \mathrm{psi}$ ). Using a diaphragm pump yielded a higher flux $\left(0.3 \mathrm{gpm} / \mathrm{ft}^{2}\right)$ but the crossflow velocity was also decreased to $2.5 \mathrm{ft} / \mathrm{s}$, versus $8 \mathrm{ft} / \mathrm{s}$ with the centrifugal pump and the differential pressure was increased (up to 60 psi). The filtrate clarity was higher with the diaphragm pump ( 70\% solids removal) versus the centrifugal pump ( 30\% solids removal).

Settling of the simulated NCAW was effective at reducing the solids content to $<50 \mathrm{ppm}$ within 24 hours. 30 Addition of coprecipitants and flocculating agents improved the settling rates, with ferric nitrate yielding the best results. Other agents tested were ferric chloride, alum, sodium chloride, potato starch, and anionic polyelectrolytes. Vessel diameters of 3 and 1 inches influenced the settling test results, presumably due to wall effects.

A Pneumatic Hydropulse filter was tested using simulated NCAW containing $1000 \mathrm{ppm}$ of insoluble solids.6 The flow rate was $1.17 \mathrm{gpm} / \mathrm{ft}^{2}$ and DE was used as both a precoat and body feed. Filtrate samples were clear with $<4 \mathrm{ppm}$ of insoluble solids. Without a DE precoat or body feed, filter blinding was observed within 25 minutes.

It was concluded that settling and decanting, followed by polishing filtration with the $\mathrm{DE}$ coated filter would meet the required separation factors. 31 Testing on radioactive samples was then conducted.

\section{Radioactive Waste}

Neutralized Current Acid Waste supernate from B Plant was tested using a Mott $(0.5 \mathrm{micron})$ Pneumatic Hydropulse Filter at Hanford.31 Two tests were conducted; one used a solution with low concentration of solids $(<500 \mathrm{ppm})$ and one used the same solution spiked with solids (to $626 \mathrm{ppm}$ ). In both cases, a DE precoat and body feed was used. The low solids sample flux of $0.2 \mathrm{gpm} / \mathrm{ft}^{2}$ indicated no increase in pressure, above the initial 3 psi, after 12 hours. Increasing the flux to $0.4 \mathrm{gpm} / \mathrm{ft}^{2}$ increased the differential pressure to $18 \mathrm{psi}$ after 29 hours. Further increasing the flux to $0.6 \mathrm{gpm} / \mathrm{ft}^{2}$ caused more rapid fouling. The cake was backflushed three 
times and the original pressure drop was restored: Using the high solids content feed, the pressure increased to 6 psi. after operating for $\sim 46$ hours at $0.2 \mathrm{gpm} / \mathrm{ft}^{2}$. More rapid fouling was observed at higher flow rates. Chemical cleaning of the filter was accomplished using $1 \mathrm{M}$ nitric acid.

A final test was conducted using no precoat or body feed in the low solids sample. The first 40 gallon batch had little effect on the differential pressure which was constant at 4 psi (flow rate was not controlled or reported). Filtration of a second batch of 20 gallons caused an increase in the pressure differential to a final of $27 \mathrm{psi}$. The solids were not removable by backpulsing. Two nitric acid cleaning cycles were necessary to clean the filter, although the filter was not completely restored to clean conditions.

During the DE-precoated runs, removal efficiencies for plutonium and americium were $96 \%$ and $98 \%$, respectively. Insoluble solids separation was reported at only $67 \%$, although analytical difficulties were noted which may have incorrectly indicated poor separation. Removal efficiency results were not reported for filtrate samples from the run without DE.

Settling and centrifuging of Neutralized Current Acid Waste supernate from B Plant was also tested at Hanford. 32 The waste samples contained 4 vol $\frac{\circ}{\circ}$ insoluble solids. The insoluble solids separation efficiency of settling was $90 \%$ after 48 hours. The americium and plutonium separation efficiencies were $98 \%$ and $95 \%$, respectively, after 48 hours of settling. The Sr-90 settling separation efficiency was $96.6 \%$, although some problems with the analysis were noted. The centrifuge tests were inconclusive due to apparent settling of the solids in the feed tank which caused low quantities of solids in the feed stream to the centrifuge. Separation efficiencies for americium, plutonium, and strontium exceeded $90 \%$, although poor material balances were observed. Large amounts of water were also required to remove the solids from the centrifuge bowi, decreasing the efficiency of the process.

\section{Colloid Chemistry Studies}

Submicron discrete sludge particles tend to agglomerate into larger (up to 100 microns) units, depending on many parameters.33 washing sludge solids with water reduces the ionic strength and $\mathrm{pH}$ of the solution and generally breaks up the large agglomerates into smaller ones. Washing does not appear to cause complete disintegration into discrete submicron particles. Pumping slurries causes shear and generally reduces the viscosity of the slurries.

Understanding agglomeration behavior versus shear, $\mathrm{pH}$, and ionic strength is critical to development of flowsheet models 
that predict the impact of variables. Pump selection, crossflow velocity, and system design are impacted by the colloid chemistry of the sludge solids.

Research is underway to identify whether setting is an effective solid/liquid separation technique at Hanford. Key parameters of the settling studies are: kinetics, sediment density, and supernate clarity. The impact of pumping and washing on these parameters are integral to determining if settling is effective. Development of low-level or nonradioactive simulants which can be used for testing solid/liquid separation techniques is also a key focus area of this research. Development of simulants will permit costefficient testing of large-scale equipment, such as pumps and filters, under a variety of conditions.

Sorption or coprecipitation of radionuclides on colloidal materials impacts the decontamination of the liquid stream. Generally, TRU species and strontium remain with the sludge fraction, but chelation by organics can cause solubilization. In addition, washing sludge may cause release of radionuclides due to reduced ionic strength of the aqueous phase, causing peptization of radioactive colloids by reducing the double layer thickness. 34 Bench-scale testing on radioactive waste is required to fully evaluate the effective of washing on radionuclide solubility.

Colloid chemistry studies of sludge at Hanford has revealed that significant quantities of micron-sized agglomerates and submicron-sized individual particles are present. 33 Although significant tank-to-tank variability is observed, the predominant identifiable species present are boehmite and gibbsite forms of alumina, iron and zirconium oxides and hydroxides, silica, and phosphate salts. The particle size of the sludge in 31 tanks has been measured, with mean particle sizes ranging from 0.5 to 30.9 microns. 35 This indicates a tremendous range in the expected performance and behavior of the sludges from various tanks. Only three tanks are reported to have mean particle sizes less than 5 microns, although the analytical techniques were not necessarily identical on all of the samples. Particle settling rates were listed for three tanks, ranging from 0.01 to $0.4 \mathrm{~cm} / \mathrm{hr}$ and were dependent on dilution ratios, viscosity, and washing techniques. Recent tests on six tanks indicate that the volume average particle sizes range from 1.5 to 2.8 microns. 36 After leaching with caustic and washing, the volume average particle sizes ranged from 1.1 to 3.1 microns. 


\section{QRNL Melton Valley Storage Tank Tests}

\section{Simulated Waste}

Simulated and radioactive wastes from MVST $W-29$ were tested using three filters: Mott stainless steel $(0.5$ and 2.0 micron), a CARRE with a ZOSS membrane (0.5 micron) 37,38 and a CARRE filter with a proprietary membrane. 37 The insoluble solids in the simulated waste were a mixture of metal hydroxides and bentonite clay. The total insoluble solids in

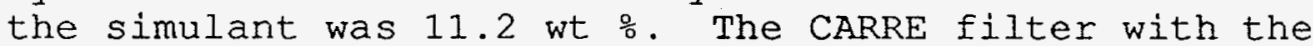
proprietary membrane degraded during simulant testing, probably due to the high hydroxide content of the solution. The Mott filters did not degrade and gave higher filtrate flux rates than the CARRE filters. The 0.5 micron Mott filter gave a filtrate flow rate of $0.039 \mathrm{gpm} / \mathrm{ft}^{2}$ at a differential pressure of 19 psi, a crossflow velocity of 4.5 $\mathrm{ft} / \mathrm{s}$, and backpulse frequency of 10 minutes. A crossflow velocity of $4.5 \mathrm{ft} / \mathrm{s}$ produced higher filtrdte flow rates than $9 \mathrm{ft} / \mathrm{s}$. The slurry volume was reduced by $67 \%$ in a 24 hour cycle with a 19 psi differential pressure.

\section{Radioactive Waste}

The filtrate flow rates obtained from the 0.5 micron Mott filter were higher on the radioactive waste from MVST W-29 than on the simulated waste. A feed velocity of $4.5 \mathrm{ft} / \mathrm{s}$, and differential pressure of 19 psi gave a filtrate flow rate of $0.1 \mathrm{gpm} / \mathrm{ft}^{2}$. The Mott $0.5 \mathrm{micron}$ pore size filter gave a $40 \%$ higher filtrate rate than the 2.0 micron, and both filters gave gross alpha rejection of $>99.8 \%$. In a long-term test on the 0.5 micron filter, the filtrate flow rate decreased gradually during the first 600 hours of the test. After 600 hours of operation, filter differential pressure was doubled to 41 psi. The filtrate flow rate was restored to the original level and was constant for the remaining 400 hours of the test. The final operating conditions were: crossflow velocity of $4.5 \mathrm{ft} / \mathrm{s}$, differential pressure of 41 $\mathrm{psi}$, and filtrate flux of $0.11 \mathrm{gpm} / \mathrm{ft}^{2}$. This flux was much higher than that observed for simulated waste, but the concentration of insoluble solids (0.5 wt $\left.\frac{\circ}{\circ}\right)$ was much lower than that used in the simulant test (11.2 wt \%). A Carre zOSS filter was also tested on this waste stream, but the filtrate flow rate was less than $10 \%$ of that observed for the 0.5 micron Mott filter.

\section{ORNL REDC Tests}

Preliminary testing is underway on simulated REDC waste solutions using a Mott crossflow filter at ORNL. Results from the tests are not yet available. A unit with a 3element Mott filter bundle will be used for testing. The simulant formulation has been described as a mixture of solid 
zirconium, aluminum, and iron hydroxides ( 3 wt $\%$ ) in a solution of sodium nitrate and sodium hydroxide. This represents the composition of the slurry after it is partially concentrated.

ORNI Newly Generated Low Level Liquid Waste Tests -

The feasibility of reducing radionuclides to required levels in simulated NGLLLW has been demonstrated in the laboratory. 8 The simulant tests included evaluating several ion exchange resins as well as coprecipitation for strontium and cesium removal. The most effective method for strontium removal was found to be coprecipitation with non-radioactive strontium (i.e. isotopic dilution) and iron hydroxide. Cesium removal was accomplished using KCCF formed in-situ as a finely divided solid in the waste. The procedure is accomplished at $\mathrm{pH} \sim 8$, causing coprecipitation with aluminum hydroxide. A pilot-scale test was done using a clarifier to remove the KCCE, but was less successful than the lab+scale testing at cesium decontamination due to difficulty in solid/liquid separation. Filtration equipment testing to demonstrate achievable decontamination factors or flow rates has not been done.

\section{Site Testing conclusions}

The experimental work and operation of the SRS ETF demonstrate that microfiltration of freshly precipitated mixtures of silica, aluminum hydroxide, and iron hydroxide is feasible with ceramic microfilters. The initial reduced performance of the facility due to bacterial fouling of the microfilters was partially caused by internally-generated bacteria, but significant amounts of bacteria were also periodically present in the influent. 39 These observations exemplify the need to both fully characterize the influent streams and test the units on actual waste.

Bacterial growth can occur in simulated waste samples, water containers, and filter lay-up solutions unless controls are enacted. Bacteria can grow under a wide variety of conditions and $\mathrm{pH}$. Biostatic doses of caustic $(0.1 \mathrm{M})$ or other biocide are a minimum requirement for storage of solutions for periods exceeding 1 to 2 days. Biological fouling can significantly reduce filtrate production rates and must be considered in design and testing of any simulant or radioactive waste treatment facility.

The SRS ITP and LW testing demonstrate the importance of scale and configuration on design. Use of four filter bundles in series results in different flow properties in each bundle, causing variable performance. 22 
The SRS ITP and LW testing also demonstrate the impact of pump shear on filter performance. Use of diaphragm pumps, which are low shear, consistently yielded better performance than centrifugal pumps, which are high shear. This

observation led to use of low-shear centrifugal pumps in the ITP and LW facilities. 40 This is also consistent with the Hanford observations of pump effects on the ability to dewater sludge. 29

The ITP acceptance testing demonstrated the importance of scale-up on the backpulse system. Backpulsing is highly efficient on the laboratory scale, but becomes less efficient with larger scale equipment. Upgrades in the equipment, over the original design, were needed to maximize the efficiency of the backpulsing.

The Hanford Redox/Purex simulated sludge tests demonstrated the effectiveness of polyelectrolytes.27 The sludges were concentrated and washed using a filter without electrolyte addition. When electrolytes were added, the simulated sludge was effectively concentrated using either gravity thickening or centrifugation.

The Hanford Cladding Removal Waste simulant tests demonstrated the potential variability of performance of wastes from different sources. 28 The results show large differences in filtrate quality on the three simulated waste streams, but only a relatively small change in filtrate flow rates. The three simulated waste streams were significantly different from one another. The filtrate ranged from less than $0.5 \mathrm{NTU}$ ( $0 \mathrm{ppm}$ of insoluble solids) to $500 \mathrm{ppm}$ of insoluble solids. Also, use of a dead-end filter versus a crossflow filter showed that fine precipitates that foul a dead-end filter will penetrate a crossflow filter due to the absence of a filter cake.

The Hanford NCAW filter testing demonstrated that good correlations can be made between simulated and radioactive wastes, both in filtrate production rates and filtrate quality. 29 However, this would be expected because DE coated filters are robust and are not as sensitive to small changes in influent characteristics. The filter performance is predominated by the presence of a large amount of diatomaceous earth. Other interesting observations include rapid filter blinding in the absence of a DE precoat when using simulant, but not as quickly with radioactive waste. The radioactive waste tests also showed that without the diatomaceous earth precoat, two nitric acid soakings did not completely restore filter performance.

The ORNI MVST tests using simulated waste demonstrated the need for long-term testing. In these tests, the non-metallic membranes can fail after extended contact with highly 
alkaline wastes. 37,38 It' was also demonstrated that a smaller pore size filter can have a higher filtrate flow rate. This trend is often seen and is attributable to the smaller pore size excluding penetration of solids into the filter pores. A larger pore filter becomes more of a "depth" filter, forming a filter cake within the filter element which causes resistance. Also, it was seen that radioactive waste had a higher filtrate flow rate, but this was at least partially due to much lower concentration of solids in the radioactive waste than in the simulated-waste.

The successful operation of the West Valley crossflow filter for several years demonstrates the potential application of crossflow filtration to sludge treatment. The use of a floating suction to permit maximum clarification of the liquid reduces the need for backpulsing and improves the filtrate flow rates. This successful operation demonstrates the feasibility of large-scale crossflow filtration of tank waste.

\section{SIMULANTS VS. ACTUAL WASTE}

The accuracy and confidence of results obtained by use of simulated versus actual waste are dependent on which waste stream is examined. For example, when examining filter performance of ITP simulant, precipitation of cesium and potassium tetraphenylborate is not dependent on whether radioactive or simulated salt solution is used. The impact on filter performance of the addition of monosodium titanate for strontium removal is also independent of the use of simulated or radioactive waste. However, variables such as the presence of insoluble. sludge in the radioactive waste will have an effect on filter performance. Testing on simulated waste under a wide variety of conditions has been used to bound the expected operating conditions. Comparisons of filter performance between simulated and radioactive waste have been critical to the testing program. Decontamination factors for cesium and strontium are independent of whether the ions are radioactive; therefore, simulants can be used to determine if the filter removes all of the insoluble solids.

In the ORNL REDC process, the insoluble solids are not stored for years but are relatively freshly precipitated. The simulant formulation should be prepared in a manner similar to the actual waste precipitation processes. Comparison to the physical and chemical characteristics of the actual waste samples can also be done. The decontamination factors for waste components must be compared in the laboratory for both simulated and radioactive waste.

In treatment of Hanford tank waste and ORNL Gunite tank remediation, it is not feasible to replicate the process chemistry (heating, radiation, aging, and mixing of waste 
streams) that generated the waste in many of the tanks. Detailed studies of the physical and chemical characteristics of the wastes are needed to develop simulants. Both physical and chemical attributes must be included in simulant

formulations. Benchmarking tests between waste and simulants under a variety of conditions are needed to ensure consistent performance. Use of simulants for bounding case studies and equipment comparisons is reasonable. Decontamination factor requirements for both streams are currently based on insoluble solids removal and therefore can be approximated using physical and chemical simulants. Radioactive waste tests on several waste types are needed for final verification of equipment selection and sizing.

The aqueous radioactive waste in the MVST supernate Cs removal program is expected to behave comparably to the simulants. Only small amounts of insoluble solids are expected to be present in this waste stream. The precipitation and settling processes can be compared for radioactive and simulated wastes in the laboratory. If the settling rates, clarity, and chemical composition are similar, filter performance is expected to be comparable. Decontamination factors for radionuclides are not applicable since the solid/liquid separation need is only as a guard to prevent solids from entering the ion exchange beds.

Simulant development is needed for MVST sludge treatment tests. The simulant used for the tank $W-29$ tests has been compared to the radioactive waste and can be used initially. Further simulant development is needed for the other MVST sludges. Simulant development should be based on physical characteristics of the waste.

The precipitation of strontium by addition of non-radioactive strontium in the ORNL NGLLLW process is independent of whether the waste is simulated or radioactive, as long as the chemical components, temperature, addition rates, and mixing are similar. Simulants precipitated under controlled conditions will behave similar to that in actual waste. It may not be possible to determine the engineering parameters, such as mixing and addition rates, using non-radioactive simulants due to the inability to distinguish strontium in. the original mixture versus added strontium. Uncontrolled variables such as the presence of insoluble (sludge) solids in the actual waste may cause variation in filter behavior. These trace insoluble solids, depending on size and morphology, may impact filter performance significantly. the second and third filtration steps in the ORNL NGLLLW process, the difference in performance between actual and simulated wastes is expected to be negligible. In these subsequent filtration steps, the waste has already been filtered once, and any sludge solids which may impact performance have been removed. As long as chemical addition rates, temperature, mixing rates, and concentrat sns remain 
constant, filtration performance should remain consistent. Since the waste formulation is based on a projected flowsheet, comparison to actual waste is not yet feasible. Decontamination factors for simulants and radioactive waste must be compared, due to the potential impact of trace contaminants on the solubility of the ions.

\section{SLS METHOD APPLICABIIITY}

\section{Hanferd}

There are three primary solid/liquid separation needs currentiy in the Hanford TWRS pretreatment flowsheet. The first application, sludge leaching and washing, may be subdivided into coarse and polishing steps. The second separation, ion exchange influent polishing, is expected to have low quantities of insoluble solids. The third separation need, ion exchange effluent fines removal, is to catch fines from the ion exchange (IX) resin.

\section{Sludge Leaching and Washing}

The first Hanford solid/liquid separation, is performed as part of the sludge washing step. This separation may be accomplished by in-tank or out-of-tank settling, similar to the in-tank sludge washing at SRS. If settling is not adequate to meet the supernate clarity requirements or bottoms solids content requirement in short time periods, other methods are needed. One option is to use a countercurrent decantation circuit (CCD). 41 A CCD is a series of sequential decantation vessels arranged to permit countercurrent flow of sludge and wash water. The CCD circuit would reduce the wash water volume requirement versus a settle and decant method. This would be a viable option only for sludges that readily settle. Centrifugation is also a possible separation method, as shown in the Hanford Redox/Purex Sludge Tests. High concentrations of polymeric flocculating agents were necessary in the testing, and would probably be needed in operations of both centrifugation and a $C C D$. Addition of organic polymers increases the potential for modifying the waste chemistry and volatile organic compound production from radiolysis. Use of centrifuges in high radiation and remote maintenance locations may be difficult to implement. The centrate clarity can also be enianced with filtration.

Crossflow filtration can be used either for polishing the supernate and wash water after a coarse settling, or it can be used. as a single step for both concentrating sludge solids and clarifying the liquid. Crossflow filtration can be used for clarifying the dissolved salt cake and supernate. Experimentation is needed to determine the optimum configuration of coarse and polishing separations. Polymeric 
filters are not expected to be capable of tolerating the high radiation fields and alkalinity of the Hanford tank waste stream. Ceramic (alpha-alumina) and ceramic (titania)/metal filters, according to the manufacturer's specifications, tolerate high alkalinity. Gasket materials for the ceramic filters may be problematic. Stainless steel filters can withstand the harsh environment of sludge and supernate separations.

Another option for polishing the clarified liquid is a deepbed filtration with an alkaline-tolerant media. However, if the sludge does not settle in a short time it suggests that the particle size of the solids is small and it may not be filterable with this method. Use of a DE precoated filter, similar to that used in the Hanford NCAW tests, is expected to be problematic with highly alkaline waste. The maximum operating alkalinity of $\mathrm{DE}$ is typically $\mathrm{pH}=11$. Other filter aids are tolerant of high alkalinity, but they are typically composed of cellulosic material. The silica in the DE partially dissolves in caustic, potentially causing downstream fouling as the silica reacts with dissolved aluminates or sorbs onto ion exchange resin.

The baseline approach at Hanford of setting and decanting is appropriate. If this does not produce a sufficiently clarified supernate, crossflow filtration, centrifugation, or deep-bed filtration should be examined. Backflushable deadend filters are unlikely to achieve sufficient filtrate flow rates, based on cursory laboratory testing. 33 Using crossflow filtration for the concentration and washing of sludge is feasible, but low filtrate flow rates are expected.

\section{Ion Exchange Influent Polishing}

The second solid/liquid separation step in the Hanford TWRS pretreatment flowsheet is to remove residual sludge solids and material that precipitates after evaporation. Testing is needed to determine if a media filter (e.g., a bed of glass frit) produces adequate filtrate and if the backwash volumes are excessive. Crossflow filtration could be an alternate treatment method. Stainless steel, alpha-alumina, and ceramic/metal filters are expected to be capable of tolerating the high radiation and alkalinity of this waste stream, although the alpha-alumina gaskets may be problematio.

The baseline technology for polishing these evaporator product streams at Hanford, fritted glass depth filtration, has not been tested on simulated or radioactive wastes. This technology appears feasible if sludge washing and settling is done, the fouling rate is sufficiently, low, filtrate quality is high enough, and if the backwash volumes can be tolerated. Testing is reeded to determine if the frit behaves like 
Perlite (an aluminosilicate) that becomes a gel which then recrystallizes as zeolite in strongly alkaline solutions. 42 Testing of this method is needed to determine if the functional performance criteria can be met.

\section{Ion Exchange Effluent Eines Removal}

A post-IX treatment method for removal of resin fines may be needed in the Hanford TWRS pretreatment flow sheet. A guard filter or screen is needed to catch the fines present in the treated effluent. Chemical cleaning of a guard filter is expected to be difficult because of the limited ability to dissolve resin fines in cleaning solutions. Dissolution of organic resin fines may be possible with strong acids, but fines from crystalline silicotitanates may be more difficult to dissolve. Use of a crossflow filter for this stream which contains low insoluble solids is not practical, and a deadend metal, polymeric, or media filter may be the best approach. The low radiation field after ion exchange would permit use of polymeric filters. Backpulsing or backwashing any of these filters may be adequate to remove the fines, reducing the need for chemical cleaning. The West valley process demonstrates that a depth filter is effective at zeolite fines removal with that waste stream.

\section{QRNL Gunite Tanks}

The sludge in the ORNL Gunite tanks will be sluiced out using water, and perhaps a suspension agent such as bentonite. Once the material is sluiced, settling the solids in another tank and reusing the water is the preferred mode of operation. If the settling rates in the second tank are too low, filtration or some other separation method is needed. A very likely candidate for the bulk of the solids removal is a hydrocyclone. The sludge is reported to settle in the tanks to as high as 35 wt $\frac{0}{\partial}$ suggesting a very dense material that may be separable with a hydrocyclone. The use of crossflow filtration is another option if the hydrocyclone is incapable of sufficient separation. A crossflow filter would allow higher filtrate flow rates and solids concentration than dead-end filtration. The abrasiveness of the solids should be considered when selecting a crossflow filter for this application. Alternatively, use of a hydrocyclone for coarse separation may be adequate for liquid reuse, followed by polishing filtration prior to final liquid disposal. The need for a polishing filter will depend on the final criteria for disposition of the water. Further characterization of the sludge and final waste water disposition criteria are needed to identify specific SLS applications and develop a test program. 
WSRC-R'P-95-0337, Rev. 0

\section{QRNI MVST Supernate Cs Rëmoval-Erogram}

The relatively low radiation level of the MVST Supernate is compatible with use of polymeric cartridge filters. The waste stream is only moderately alkaline and contains only trace amounts of insoluble solids. Use of a backwashable cartridge filter would permit extended use of the filter and reduced radiation levels of the cartridges when they are disposed. Crossflow polymeric filters could also be used, but the cost and complexity of the unit is probably not needed for this low solids and low flow rate waste stream.

\section{ORNL MVST TRU Processing Facility}

The requirements for the ORNL MVST sludge solid/liquid separation step are not fully defined. It is expected that a solid/liquid separation technique will be performed as part of a sludge washing step. This separation may be accomplished by in-tank or out-of-tank settling, similar to the in-tank sludge washing at SRS. If settling is not adequate to meet the supernate clarity requirements other methods are needed. Options include use of a countercurrent decantation circuit, centrifuge, or a crossflow filter. Using a crossflow filter to concentrate the REDC waste is expected to require a metal, ceramic, or ceramic/metal filter due to the high radiation levels of this waste stream.

\section{ORNL REDC}

The ORNI REDC waste stream is expected to contain <1 wt insoluble solids but a high concentration of radionuclides. Concentrating the slurry to 10-15 wt $\frac{\circ}{0}$ insoluble solids is not practical with cartridge or multimedia filtration. Other types of dead-end filters would not concentrate the solids to the high solids content. Crossflow filtration is expected to permit concentration of the solids at high flow rates. Another option is to settle the solids, filtering only the clarified supernate with a dead-end, multimedia, or crossflow filter. Lab-scale testing would be needed to determine if the solids settle to a sufficiently dense cake to permit this treatment approach.

Using a crossflow filter to concentrate the REDC waste is expected to require a metal, ceramic, or ceramic/metal filter due to the high radiation levels of this waste stream. The high alkalinity and radiation may limit the gaskets used in ceramic filters.

\section{ORNI, NGLILW}

The precipitates of strontium carbonate, and KCCE in the ORNL NGLLLW process are expected to be fine, although one test indicated that the KCCF could be removed with a $0.45 \mu$ 
filter. ${ }^{8}$ The $\mathrm{pH}$ adjustment step also forms aluminum hydroxide, which is commonly a gel under these conditions. The pilot testing suggests that the material is probably too fine to settle by gravity. The insoluble solids content in the first filtration step (i.e., strontium precipitation) is approximately $200 \mathrm{mg} / \mathrm{L}$. The maximum projected radiation level (i.e., $0.1 \mathrm{Ci} / \mathrm{L}$ of $\mathrm{Cs}-137$ and $\mathrm{Cs}-134,0.13 \mathrm{Ci} / \mathrm{L}$ of $\mathrm{Ru}-$ 106 and $\mathrm{Ru}-103$, and $0.02 \mathrm{Ci} / \mathrm{L}$ of $\mathrm{Sr}-90$ ) is an intermediate level for a" polymeric filter, but tolerable for ceramic or metal filters. Filters constructed of fluoropolymers are expected to exhibit radiation damage over extended contact, but those constructed of other polymers are expected to be more resistant.

The alkalinity of the solution in the first step (i.e., strontium precipitation) of the NGLLLW process is probably too high for most polymeric filters, but is within the limit of the tolerable range of ceramic filters constructed of alpha-alumina. Ceramic filters constructed of other types of alumina are less tolerant to high alkalinity. ${ }^{9}$ Diatomaceous earth or other aluminosilicate filter aids are not tolerant to the high alkalinity of the unadjusted NGLILW stream, excluding the use of a precoated dead-end filter for the first step. Subsequent treatment steps in the NGLLLW process are at ambient $\mathrm{pH}$ and would not be a concern for any filter.

In the first two NGLLLW steps (i.e., strontium precipitation and the first KCCF strike), the insoluble solids content is at the limit of cartridge filtration viability. The precipitate particles in the first two steps are probably too small to permit multi-media filtration. The third step (second KCCF strike) could utilize cartridge filtration, but removing the cesium from the cartridges to get it into an acceptable waste form would probably require chemical cleaning.

Crossflow polymeric filters may be acceptable for the second and third steps of the NGLLLW process although there are several issues to be resolved. The primary problem with polymeric filters is expected to be chemical cleaning. The KCCF solids need to be dissolved to clean the filters and the pH required to dissolve it may be outside of the tolerable range for the filter material. Cobalt ferrocyanides are known to be stable to $1 \mathrm{M}$ acid but decompose above $\mathrm{pH}=11.10$ polymeric filters made from non-fluoropolymers with submicron pore sizes are readily available, but generally have a lower chemical tolerance than those made of fluoropolymers.

Decontamination for disposal of the filters may be done with slightly higher caustic or acid concentrations because the integrity of the filter pores would no longer be important. Alternatively, some polymeric filters are available that utilize mechanical (sponge-ball) cleaning, which would avoid chemical cleaning problems. 
Crossflow ceramic or metal filters are the most likely filter candidates for the first and second steps (strontium precipitation and the first KCCF strike) of the NGLLLW process. A submicron pore size will probably be required to remove the fine precipitates. The aluminum hydroxide precipitate in the second filtration step will act, as a filter aid to assist in removal of the $\mathrm{KCCE}$ solids. Chemical cleaning of both filter types can be accomplished with acids and bases, provided the KCCF decomposition is addressed.

Because of the low quantity of fine solids, the third step in the NGLILW process (the second KCCF strike) may be completed using a DE coated metal filter. The fine precipitate of KCCE would not reach the filter surface due to the DE, and would be removed by backpulsing. Disposal of small quantities of $D E$ can likely be done in the final wasteform.

To reduce system complexity and cost, using common filtration equipment for the first two steps may be feasible. The technology most likely to be successful for both steps is crossflow ceramic (or ceramic/metal) filtration because of the small pore size and chemical and radiation tolerance. Significant testing would be needed to prove the viability of this approach.

\section{TESTING NEEDS}

\section{Simulant Preparations}

Simulant waste formulations have been prepared for the ORNL REDC and NGLLLW processes, and for a Hanford waste tank (C103). These simulants can be used for preliminary studies to evaluate solid/liquid separation technologies. Simulant development is needed for the MVST supernate cesium removal program, the Gunite Tanks remediation, and other Hanford tanks.

The formulation of simulated Hanford tank sludge should be based on the measured physical properties of the radioactive sludge. The Hanford tank wastes vary widely in chemical and physical characteristics. Years of mixing, aging, and settling in the tanks have formed waste compositions that are expected to have variations in primary particle size, agglomeration behavior, viscosity, and solubility which do not reflect the original waste form. Earlier testing that was done on crossflow filtration, centrifugation, settling, and other SIS techniques is not likely to be fully representative of the current waste. The earlier work on NCAW, Redox, Purex, and Cladding Removal wastes yielded widely varying results. The effects of combining and aging these wastes on SIS techniques cannot be predicted because of formation of different compounds and the potential for 
synergistic effects. The data from previous test's can be used for general observations and indications of expected SLS method performance.

Further work is necessary to more fully characterize Hanford waste tank compositions other than tank C-103 and develop simulants. This work is currently being done at Hanford and Los Alamos. Characterization of the minor insoluble constituents is needed, particularly for chemical cleaning studies. Comparisons of settling, filterability, particle size, and chemical compositions between simulated and radioactive tank waste are needed to ensure accurate simulant formulations. The sludge composition of each tank will need to be characterized, and perhaps the waste types can be placed in several broad categories to minimize testing. Identifying filter performance on each individual waste origin (e.g., Purex versus Redox sludge), and estimating performance based on mixtures cannot be done because the waste types can have a synergistic effect on filter performance. Sludge solubility studies are needed to determine what solutions can be used to clean filters.

In addition to the insoluble solids, the characteristics of the aqueous phase of simulants must be similar to that of the waste. Viscosity, density, $\mathrm{pH}$, and chemical composition of the liquid phase will be significant, especially in the selection of settling or centrifugation equipment.

\section{Simulant Testing}

\section{SRS In-Tank Precipitation and Late Wash}

Testing is needed to verify that use the DWPF recycle stream (condensate from evaporation and melting) to dissolve salt cake in the tank farm will not adversely effect filter performance. Suspended solids contained in this stream may cause filtration problems in both the ITP and LW facilities. The composition of the solids in the recycle stream need to be evaluated, accurate simulants developed, and tested on the Mott crossflow filters.

Similarly, use of ESP wash water to dissolve salt cake in the tank farm must be evaluated. The wash water may contain a significant quantity of sludge that does not settle because of the fine particle size. The presence of insoluble siudge solids in this waste stream may impact filtration in ITP and LW. This alteration in the flowsheet needs to be evaluated with accurate simulants being developed and tested on the Mott crossflow filters. 
Hanferd Tank Waste Sludge Leaching and Washing

Testing is needed to determine if settling is adequate treatment for the Hanford tank waste sludge. An evaluation of the volume of caustic leach solution, wash water, and sludge is needed. Preliminary tests can be done wi,th simulants, but the majority of this testing should be done with radioactive waste samples. An evaluation of the available equipment, tank space, and evaporator capacity are also needed. Whether the settling is in-tank or out-of-tank needs to be included. If settling is adequate to clarify the liquid for evaporation, this is the most desirable sLS method. Other settling methods, such as counter-current decantation and clarifiers should be considered to enhance system efficiency.

If settling of the Hanford tank waste sludge is not acceptable, crossflow filtration needs to be tested for the coarse sludge solid/liquid separation. The most compatible and effective crossflow filters are expected to be the metal or metal/ceramic filters. This includes the sintered metal and etched metal disk filters. Preliminary studies should be done with the ceramic filters to determine if significant improvements in performance can be realized. If the ceramic filters are significantly better than metal filters, a detailed study of the gasket material tolerance to radiation and caustic is needed. Other types of crossflow filters are not likely to be applicable due to the high abrasiveness and alkalinity. Abrasiveness of the sludge on the filter medium must be evaluated.

Centrifuges should also be considered for the coarse sludge separation at Hanford. Evaluation of centrifuges should consider: chemical effects of adding polyelectrolytes to the waste, maintainability of the equipment, centrate quality, and flow rates. Accurate simulation of the viscosity and density of the liquid portion of the simulant solution is critical to the applicability of simulant testing. Although a hydrocyclone may be applicable to some sludge types, it is unlikely to be effective with sludges containing submicron particles.

Filtration studies of the polishing SLS are needed. It may be advantageous to settle the bulk of the sludge and filter only the decanted liquid. This needs to be done in conjunction with an evaluation of the influent requirements for the evaporator. Filters to be examined for this separation include those listed above for the coarse separation as well as a deep bed filter. The most likely candidate for this separation is the smaller pore metal/ceramic filter. The simulant should be prepared by setting a concentrated slurry and decanting the liquid. 
It is important to include in testing the variations in the aqueous phase as well as the solid phase. Depending on the final flowsheet, the sodium content of the aqueous phase can range from over $10 \mathrm{M}$ to less than $1 \mathrm{M}$. The range of sodium content corresponds to changes in the viscosity and density of the liquid, which effects filtration, settling, and centrifugation properties. The liquid phase also effects the colloid chemistry of the sludge and the surface charge of the filter and colloids. Demonstrations of equipment must include sludge washing studies to evaluate these effects, as well as chemical cleaning studies.

With the variety of sludge types present in Hanford tank waste, it is apparent that any one solid/liquid separation technology will not be equally effective for all waste types. This is evident by comparisons of the simulated Hanford Redox/Purex Sludge, Hanford NCAW, and the Hanford Cladding Removal Waste tests. Contingencies for alternate technologies, or variations on the primary, technology, to treat other streams must be considered in flowsheet development. The system design must be sufficiently robust to permit variations in waste treatment flow rates. The major simulant formulations developed for the variety of waste tanks needs to be tested on the most promising technologies.

The wastes need to be analyzed sufficiently to permit production of several major simulant formulations and SLS techniques examined using these simulants. The precise number of simulants will depend on the results of the analyses. The critical parameters to simulate are: primary and agglomerate particle size, chemical composition, and viscosity.

Use of a settling step for sludge filtration has been effective at West Valley, and may be applicable for the Hanford tank waste. The floating suction on the pump minimizes the insoluble solids content in the filter feed solution. Backpulsing was only needed when the tank level was low and solids were pumped to the filter. If a polishing Fiter is needed after settling the sludge, consideration should be given to use of this floating suction.

Testing is also needed to establish the quantity of radionuclides that pass through filters with a range of pore sizes. Preliminary tests can be done using dead-end filters. Tests need to be conducted on the SLS technique selected for tre sludge separation steps.

Ënferd Ion Exchange Influent Polishing

I.:e pre-ion exchange SLS step in the Hañford flowsheet favors - $\lambda$ e use of crossflow filters. The same filters considered 
for the coarse separation should be examined for the polishing separation (i.e., crossflow stainless steel, metal/ceramic, and ceramic). In addition, the baseline technology of a deep bed filter needs to be evaluated. In addition to filter studies with the deep bed filtex, the evaluation of chemical compatibility of the bed material with the aqueous phase needs to be done. The simulant used for testing this waste stream should be prepared by evaporation of an aqueous phase to the appropriate concentration. The evaporation may cause formation of insoluble species other than what are present in the sludge (such as carbonate salts) that may have different performance.

Dead-end metal filters that are not precoated are expected to have low flow rates and will be difficult to clean, based on the radioactive NCAW tests.

If crossflow or deep bed filtration is not acceptable, filtration using precoated dead-end metal filters should be considered. The addition of filter aid (precoat) to the waste stream would need to be evaluated to determine the impact on (a) waste volume, (b) glass compatibility, and (c) chemical compatibility with the aqueous phase. Prior to proposing use of this method for polishing filtration at Hanford, studies of the impact of the filter aid is needed. Use of a $D \vec{E}$ to precoat a filtex is expected to cause silica fouling of the filter as the material disintegrates in the highly alkaline waste. The silica would subsequently need to be chemically cleaned. Since the kinetics of DE dissolution are difficult to predict, the testing of this SLS technique should include long-term contact studies to determine the impact. Subsequent $D E$ impacts on downstream processes also needs to be evaluated. The reactive alumina species present in the waste must be included in the simulant to evaluate reaction with $D E$ and formation of insoluble aluminosilicates, which would cause chemical cleaning problems. Alkalinetolerant cellulose-based filter aids are available, but generate a secondary waste stream that must be disposed.

Integrated tests are also needed to verify that the product of one process step is adequate for the subsequent treatment step. The filtrate from the second Hanford SLS step is fed to the ion exchange units. The filtrate quality must be adequate to prevent bed fouling and to satisfy downstream TRU componert criteria. The prevention of bed fouling can only be adequately demonstrated using an integrated test.

Similarly, the evaporator bottoms must be used as influent to the polishing filter. The hold-time and temperature of the evaporator bottoms can significantly impact the performance of the polishing filter. The routine operating conditions and upset conditions should be tested.

Testing is needed to establish the limit of insoluble solici: content of the ion exchange infiuent must be determined for 
the Hanford flowsheet. The quality of the product from any of the SLS techniques is a critical parameter for selection of the appropriate unit.

\section{Hanford Ion Exchange Effluent Eines Bemoval}

The post-ion exchange guard filter in the Hanford 'flowsheet can be a dead-end backflushable filter because of the very low solids content. Use of either a metal or polymeric filter should be examined for this application. Use of a backflushable filter will extend the filter life and minimize the quantity of radiation-containing particulates in the filter when it is disposed. Testing of the fines removal technology needs to be conducted in conjunction with ion exchange testing. Use of a depth filter, similar to that used at West valley, would have the same chemical reactivity problems associated with its use in a polishing filter and is not likely to be effective.

\section{ORNL Gunite Tank Waste}

As noted above, settling in a small tank is the desirable method for separating the bulk of the insoluble solids from the liquid in the Gunite Tanks remediation. Settling rate studies are needed to determine if this approach is effective. If the settling tests indicate that other methods are needed, simulant development and testing are needed. Effluent treatment requirements are also needed. If the bulk of the solids can be settled in a coarse separation, and the water reused for sluicing operations, this will minimize water volume. If the water must then be further clarified before transfer to a new MVST, other SLS methods are needed. For the coarse separation, a hydrocyclone should be tested. The hydrocyclone may be highly effective since the liquid has a low viscosity and the solids are probably dense. If the water must be further clarified for reuse or transfer to the MVST, crossflow filtration needs to be tested. The potentially abrasive nature of the solids suggest that metal, metal/ceramic, or ceramic (alpha-alumina) filters should be used.

\section{ORNL MST Supernate CS Removal Program}

The relatively low radiation level, low solids loading, and moderate $\mathrm{pH}$ of the MVST supernate are compatible with use of metal or polymeric (dead-end) cartridge filters. To minimize secondary waste generation, metal filters can be used, although use of backwashable polymeric filters is expected to be less expensive. Use of polymeric cartridge filters that are backwashable would extend filter life and reduce the concentration of radicactive material in the cartridges when they are disposed. These backwashable filters should be cestes using simulated raste or radioactive waste in the 
laboratory. Crossflow pölymeric filters could also be used, but the cost, size, and complexity of these units are probably not needed for this low solids and low flow rate waste stream.

QRNL MVST TRU Processing Eacility

The ORNL MVST sludge removal is very similar to the Hanford sludge processing and a similar approach is needed. Studies are needed to determine if in-tank washing and settling are adequate to wash and clarify the sludge. Evaluations of outof-tank washing methods, such as a CCD, need to be conducted. If the supernatant clarity is not adequate, further treatment is required. For treatment studies, analysis of sludge characteristics is needed and simulants need to be developed. Initially, the simulants used for the $w-29$ test can be used and benchmarked against the available data. Treatment studies should include crossflow metal and metal/ceramic filters. If the crossflow filters are not, satisfactory, a centrifuge should be tested.

\section{QRNL REDC}

For the ORNL REDC waste, crossflow filtration with metal filters is expected to be the optimum technology available. To concentrate the dilute slurry to 10 to 15 wt $\%$ solids will require crossflow filtration. Testing of this method is underway. The metal/ceramic filters are potential alternates if the metal filters cannot produce sufficient

decontamination of solids. If these technologies are inadequate, another option is to settle the solids, filtering only the clarified supernate with a dead-end, multimedia, or crossflow filter. Lab-scale testing would be needed to determine if the solids settle to a sufficiently dense cake to permit this treatment approach.

\section{ORNL NGLLLW}

Testing of SLS technologies for the first step of the ORNL NGLILW process should focus on metal, metal/ceramic, or ceramic filters. If these methods are unsuccessful, backflushable dead-end filters may be applicable, but would probably have lower flow rates than crossflow filters and generate more secondary waste.

The KCCF precipitates in the second ORNL NGLLLW process step coprecipitate with aluminum hydroxide at ambient $\mathrm{pH}$ and should be tested using crossflow ceramic or ceramic/metal filters. Removal of fine precipitates of KCCF will be more effective with a smaller pore filter than is available with the metal filters. The use of crossflow metal filters is an option, but is less likely to be successful due to the larger pore size. Data on the dissolution rates of $\mathrm{KCCF}$ and a 
knowledge of the byproducts of decomposition are needed to determine appropriate chemical cleaning parameters.

The third ORNL NGLLLW process step (second KCCF strike) should be tested with a DE coated metal filter. The fine KCCF precipitate would be absorbed by the DE and removed by backpulsing. Disposal of small quantities of $D E$ cán likely be done in the final wasteform. Alternatively, backflushable cartridge filters may be acceptable. Research would be needed to demonstrate removing the cesium from the cartridges to obtain an acceptable waste form. Chemical cleaning of the filters may be needed to sufficiently decontaminate the filters.

System complexity and cost may be reduced by using common filtration equipment for at least the first two ORNL NGLLLW steps. Use of a crossflow filter for the third step is feasible, but the low solids loading makes it less practical. The technology most likely to be successfuf at both steps is crossflow ceramic (or ceramic/metal) filtration because of the small pore size and chemical and radiation tolerance. Testing of this approach is needed.

\section{Radioactive Waste}

In general, benchmarking of simulant performance to radioactive waste performance must be completed early in the testing programs. This benchmarking can be done on a laboratory scale initially, but must be scaled up as the program proceeds. The quantity of radioactive waste treated should also be comparable to at least a single filtration cycle (i.e., gallons of waste treated per square foot of filter area in the period between planned chemical cleanings). Chemical cleaning is also a critical parameter to demonstrate with radioactive waste.

For the Hanford tank waste sludge separation, simulants and radioactive waste need to be compared on the laboratory scale for the widest range of wastes feasible. As the characterization of the waste tanks proceed, and if wastes can be categorized into general ranges, comparison tests for each category need to be completed. The filtrate flow rates and decontamination factors can be derived from these tests.

Pilot scale testing of solid/liquid separation of Hanford radioactive sludge waste is needed for "typical" waste. The scale up is needed to verify equipment performance characteristics. Operation of a pilot scale unit that is 5 to $10 \%$ of the surface area of the full scale facility must also utilize the same configuration (i.e., filter tube diameter, length, number of filters in sequence, etc.). 
Integrated testing using" radioactive waste is needed to confirm the results observed in the simulant tests. The sludge separation, evaporator concentrate separation, and the ion exchange fines removal need to be tested in sequence to verify performance.

If the current analysis program on the ORNL Gunite-Tanks indicates that settiing is not adequate, further testing is needed using radioactive samples. The tests should be done on the laboratory scale and scaled up to the pilot scale. The results should then be benchmarked against the simulated waste studies.

The solid/liquid separation for the MVST Supernate cesium removal program should be tested on the laboratory scale with radioactive waste samples. Testing on single filter elements should be adequate. The relatively low flow rate of the process does not require scale up prior to implementation.

The MVST sludge setting tests need to be completed on radioactive waste samples (some of this work has been completed43). If treatment with a crossflow filter or other SLS technique are needed, testing on the laboratory-scale is adequate. The relatively low flow rate of the process is approximately the same size as many pilot-scale facilities.

The scale of the ORNL REDC tests currently planned are similar to the required flow rates for the facility. Further scale up is not needed. Comparisons of the radioactive waste with simulated waste is needed to verify the expected performance.

The ORNL NGLLLW flow rates are also low enough that single filter elements or modules will give sufficient scale up information. Benchmarking of simulants to radioactive waste is needed to confirm both filtrate flow rates and decontamination factors.

\section{CONCLUSIONS}

Crossflow filtration has been successfully demonstrated on several types of simulated and radioactive wastes in the DOE complex, but a comprehensive examination of applicability has not been done. There are several potential applications of crossflow filtration in planned waste treatment projects. These applications have potential to reduce cost and increase efficiency of waste treatment, but testing is necessary to verify the feasibility. On some waste steams, such as the Hanford TWRS, tank-to-tank waste variability are expected to cause large variations in filterability. An extensive simulant development program is needed to characterize the wastes and demonstrate the treatability of each waste stream. Extensive testing is needed to verify the feasibility of both 
baseline and proposed alternate technologies, such as crossflow filtration, using simulated wastes. Benchmark testing using samples of radioactive waste is crucial to confirming the applicability of a specific technology.

\section{ACKNOWLEDGMENTS}

The following individuals were particularly helpful in the gathering of information and discussing technical details of the programs: at ORNL, T.E. Kent and W.D. Bond; at Hanford, J.G.H. Geeting, B.C. Bunker, and B.A. Reynolds. This work was done as part of the Office of Technology Development Tank Focus Area program (TTP \#SRI-4-20-11); C.P. MCGinnis, Pretreatment Technical Integration Manager; D. Geiser, office of Technology Development Program Manager.

\section{REFERENCES}

1. Lane, A.G., and Kirkbride, R.A., "Annual Report of Tank Waste Treatability", WHC-EP-0365-3, September, 1993.

2. Ryan, J.P., Stimson,R:E., "Technical Data Summary F/H Effluent Treatment Eacility", DPSTD-84-114, December, 1984.

3. P.D. d'Entremont, R.A. Jacobs, J.R. Eowler, D.F. Brown, D.J. McCabe, D.D. Walker, and J.M. Gillam, "High Level Waste System Process Interface Description, Functions and Requirements of the High-Level Waste Process (U) ", WSRC-TR94-0442, Rev. 1, March, 1995.

4. Dalton, W.J., private communication, December 7, 1994

5. Orme, R., "TWRS Process Flowsheet" Rev. 0, WHC-SD-WM-TI613, June 29, 1994.

6. Memo, January 11, 1995, J.G.H. Geeting and B.A. Reynolds to Distribution, "Summary Level Discussion and Meeting Minutes from the Solid/Liquid Separations Seminar held in Richland, Washington, December 7-9, 1994".

7. Kent, T., private communication, June 21, 1995.

S. W.D. Arnold, D.T. Bostick, M.W. Burgess, P.A. Taylor, J.J. Perona, and T.E. Kent, "Laboratory Development of Methods for Centralized Treatment of Liquid Low-Level Waste at Oak Ridge National Laboratory", ORNL/TM-12786, October, 1994.

a. J. Murkes, C-G Carlsson, "Crossflow Eiltration, Theory and Zractice", J. Wiley \& Sons, New York, 1988. 
10. Haas, P.A., "A Review of Information of Ferrocyanide Soids for Removal of Cesium from Solutions", Separation Science and Technology, 28 (17\&18), pp. 2479-2506, Marcel Dekker, Inc., 1993.

11. Georgeton, G.K., and Poirier, M.R., "Alternative Filtration Testing Program: Preliminary Evaluation of Filter Test Results", WSRC-RP-90-1145, September 28, 1990.

12. McCabe, D.J., Hazen, T.C., "Effects of Bacteria Concentrations on the F/H-Effluent Treatment Facility (U) ", WSRC-RP-90-798, August 7, 1990.

13. McCabe, D.J., Poirier, M.R., "Improvement in the Filtration of Bacteria-Containing Simulants by the Addition of High Levels of Aluminum(III) Nitrate (U)", WSRC-RP-90-566, June $11,1990$.

14. Poirier,M.R., and Stapf, P.M., "Baseline Testing of the Pilot-Scale Ceramic Filter Unit at the E/H ETE", WSRC-RP-92742, June 1, 1992.

15. Hay, M.S., Bibler, N:E., "Characterization and Sludge Washing Studies of Tank $42 \mathrm{H}$ Sludge (U)", WSRC-RP-94-730, July 27,1994 .

16. Motyka, T., "Technical Data Summary for In-Tank Sludge Processing", DPSTD-84-100, April, 1984.

17. L. Lee, L.L. Kilpatrick, "A Precipitation Process for Supernate Decontamination", DP-1636, November, 1982.

18. Morrissey, M.F., "Adding Sodium Titanate to ITP Simulant (U) ", WSRC-RP-93-424, March 23, 1993

19. Schmitz, M.A., "Precipitation Test Facility - Run 2 and Run 3", DPST-82-494, April 14, 1982.

20. Heng, C.J., "Salt Decontamination Demonstration Technical Summary", DPSP 83-17-17, January 5, 1984.

21. Meyer, M.L., "In-Tank Precipitation (ITP) Crossflow Filter Documentation Summary (U)", WSRC-RP-92-894, July 17, 1992 .

22. C.J. Heng to P.J. Shippy, "In-Tank Precipitation Upgraded Eilter System", February 14, 1984.

23. Peterson, R.A., "Impact of Insoluble Solids on Filtration Performance (U)", WSRC-TR-95-0077, February 28, 1995.

24. Morrissey, M.F., Dworjanyn, L.O., "Initial Technical Sasis for Late Washing Filter Cleaning (U)", WSRC-RP-92-925, ruly $23, \quad-992$. 
25. Morrissey, M.F., "Filtering Reprecipitated Slurry (U)", WSRC-RP-92-1029, August 31, 1992.

26. McCabe, D.J., Meyer, M.L., "Late Washing Filter Cleaning Cycle Demonstration (U)", WSRC-RP-92-1027, August 31, 1992.

27. Hodgson, K.M., "Status of Solid/Liquid Separation Development for Separation and Concentration of Hanford HighLevel Defense Waste", RHO-CD-846, December, 1979.

28. Bullough, B.D., "Cladding Removal waste Filtration Studies", SD-CP-DTR-018, December 14, 1988.

29. Bullough, B.D., "Centrifugation and Inextial Filtration of NCAW", SD-WM-TRP-021, 1986.

30. Bullough, B.D., "NCAW Solid/Liquid Separation via Sedimentation", SD-WM-TRP-024, March 3, 1987.

31. Kimura, M.L., Simmons, F.M., "WESF Pneumatic Hýdropulse Filter Process Test", SD-WM-PTR-007, April 14, 1987.

32. Gerboth, D.M., "B Plant NCAW Process Test Report", SD-WMPTR-006, May 12, 1987.

33. Bunker, B. private Communication, December 7, 1994

34. Bunker, B. private communication, August 2, 1995

35. Willingham, C.E., "Thermophysical Properties of Hanford High-Level Tank Wastes - a Preliminary Survey of Recent Data", PNI-9419, March, 1994.

36. Temer, D.J., Villarreal, R., "TWRS Pretreatment Technology Development Project Sludge Washing and Caustic leaching Screening Tests of Hanford Tank Sludges", presentation to Technology Assessment Panel, June 20, 1995.

37. Fowler, V.L., Hewitt,J.D., "Filtration of Oak Ridge National Laboratory Simulated Liquid Low-Level Waste", ORNL/TM-10653, August, 1989.

38. Fowler, V.L., Hewitt, J.D., "Cross Flow Filtration of Oak Ridge National Laboratory Low-Level Waste", ORNL/TM-1074, December, 1989.

39. McCabe, D.J., Hazen, T.C., "Effects of Bacteria Concentrations on the F/H-Effluent Treatment Eacility (U) ", iNSRC-RE-90-798, August 7, 1990.

40. Schmitz, M.A., "Precipitation Test.Eacility - Run 2 and Run 3", DPST-82-494, April 14, 1982. 
41. Shanahan, K.L., "Initial Studies of a Just-in-Time ESP Process (U)" SRT-EMS-95-0015, March 2, 1995.

42. Jantzen, C.M., to be published.

43. Ceo, R.N., Sears, M.B., Shor, J.T., "Physical oharacterization of Radioactive Sludges in Selected Melton Valley and Evaporator Facility Storage Tanks", ORNL/TM-11653, October, 1990.

44. Bibler, J.P., Oblath, S.B., Siler, J.L., Wiley, J.R., "Summary of ETE Process", DPST-88-303, Rev. 1, March 17, 1988 .

45. Choi, A.S., "HLW Flowsheet Material Balance for DWPE Rad Operation with Tank 51 Sludge and ITP Cycle 1 Precipitate (U)", WSRC-TR-95-0019, Rev. 0, April 19, 1995.

46. Walker, D.D., and Schmitz, M.A., "Technical Data Summary of ITP Processing of Soluble High Level Waste", DPSTD-84-103, May 1984.

47. Stone, J.A., Kelley, J.A., McMillan, T.S., "Sampling and Analyses of SRP High-Level Waste Sludges", DP-1399, August 1976 .

48. Jones, E.O. and Colton, N.G., "Hanford Single-shell Tank Waste: Preliminary Pretreatment Testing of Simulated Wastes", The Seventh Annual DOE Model Conference (Published Proceedings), October 14-17, 1991, Oak Ridge, TN

49. "Results of Eall 1994 Sampling of Gunite and Associated Tanks at the Oak Ridge National Laboratory, Oak Ridge, Tennessee", ORNL/ER/Sub/87-99053/74. 


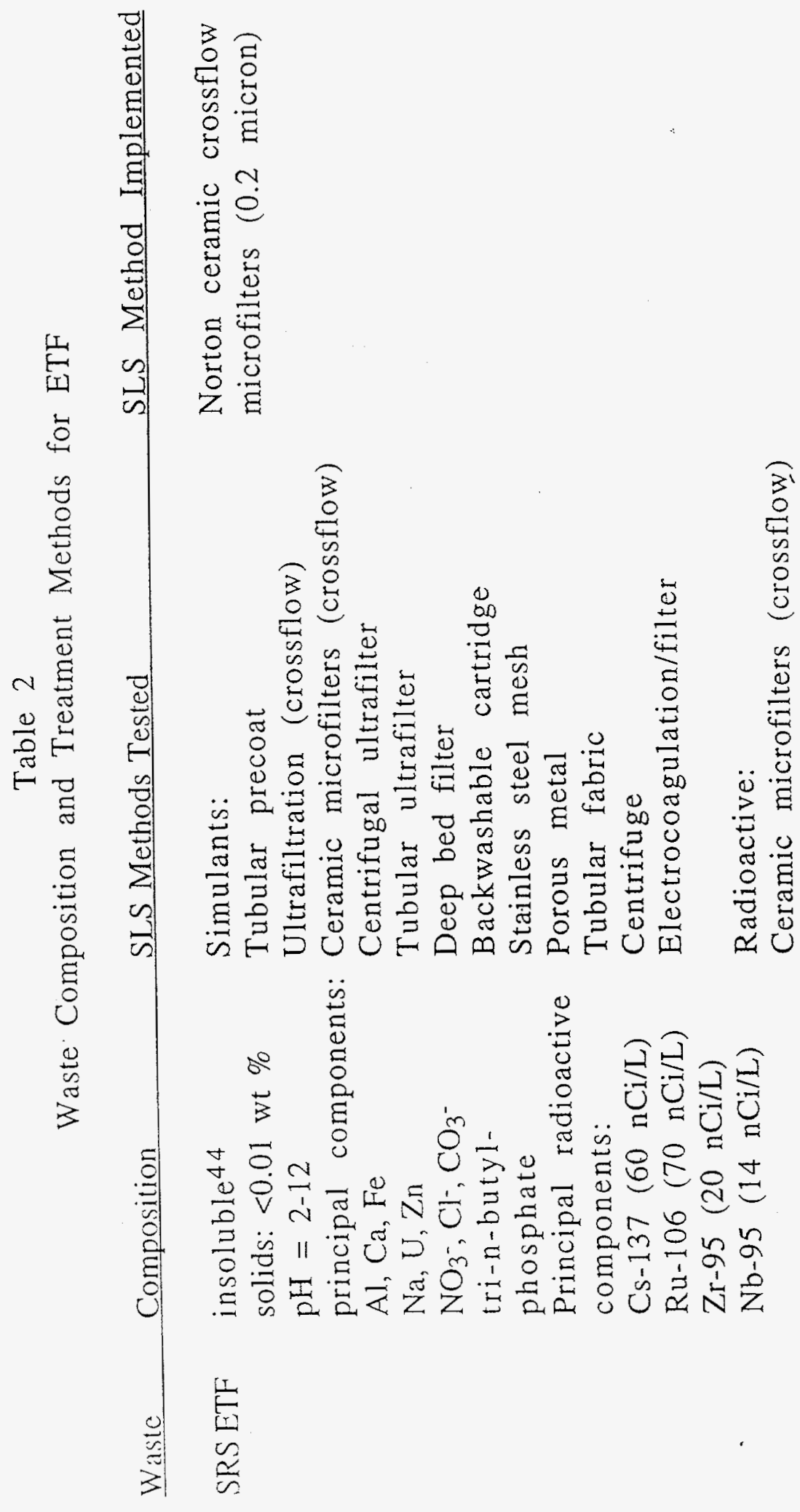


Table 3

Waste Composition and Treatment Methods for ITP

Waste

SRS ITP
Slurry

SLS Methods Tested

Simulants:

Mott stainless steel crossflow

solids: 1 wt \% $\mathrm{pH}=14$

principal

$\mathrm{Na}, \mathrm{Al}, \mathrm{K}$,

$\mathrm{OH}^{-}, \mathrm{NO}_{3}^{-}, \mathrm{NO}_{2}^{-}$

$\mathrm{CO}_{3}, \mathrm{SO}_{4}=$

Principal radioactive

components 46 :

Cs-137 (0.7 Ci/L)

$\mathrm{Sr}-90(0.2 \mathrm{mCi} / \mathrm{L})$

$\mathrm{U}, \mathrm{Pu}$
SLS Method Implemented

Mott s.s. crossflow

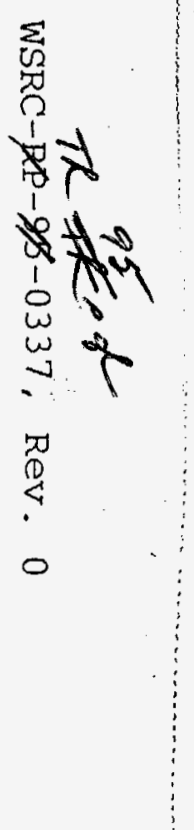


Table 4

Waste Composition and Treatment Methods for ESP

$\begin{array}{llll}\text { Waste } & \text { Composition } & \text { SLS Methods Tested } & \text { SLS Method Implemented } \\ \text { SRS } & \text { insoluble15 } & \text { Simulants: } & \text { In-tank settling } \\ \text { Sludge } & \text { solids: 20 vol } \% & \text { Settling } & \\ & \text { pH }=12 & \\ & \text { principal components: Radioactive: } & \\ & \mathrm{Na}, \mathrm{Al}, \mathrm{Fe} & \text { Settling } \\ & \mathrm{Mn}, \mathrm{Ca}, \mathrm{U}, \mathrm{Mg} & \\ & \mathrm{NO} 3^{-}, \mathrm{NO}^{-} & \\ & \text {Principal radioactive } & \\ & \text { components } 47 \\ & \mathrm{Cs}-137(0.8 \mathrm{mCi} / \mathrm{g}) & \\ & \mathrm{Sr}-90(36 \mathrm{mCi} / \mathrm{g})\end{array}$


Table 5

Waste Composition and Treatment Methods for Hanford Tank Waste

\begin{tabular}{|c|c|c|c|}
\hline Waste & Composition & SLS Methods Tested & $\begin{array}{l}\text { SLS Methods Recommended } \\
\text { for Testing and Evaluation }\end{array}$ \\
\hline $\begin{array}{l}\text { Hanford } \\
\text { Tanks }\end{array}$ & $\begin{array}{l}\text { Insoluble } 48 \\
\text { solids: max.10 wt \% } \\
\text { pH }=12-14 \\
\text { principal components: } \\
\mathrm{Al}, \mathrm{Si}, \mathrm{Fe}, \mathrm{Na} \\
\mathrm{P}, \mathrm{Bi}, \mathrm{Zr}, \mathrm{Ca} \\
\mathrm{OH}^{-}, \mathrm{NO}_{3}^{-}, \mathrm{NO}_{2}^{-}, \mathrm{SO}_{4}=\end{array}$ & $\begin{array}{l}\text { Simulants: } \\
\text { Redox/Purex: } \\
\text { Centrifuge, Settling, } \\
\text { Air flotation, Mott crossflow } \\
\text { Cladding removal: } \\
\text { Centrifuge, Settling, } \\
\text { Mott crossflow, } \\
\text { Mott iPHP } \\
\text { Crossflow s.s. filters } \\
\text { NCAW: } \\
\text { Centrifuge, Settling } \\
\text { Mott crossflow, } \\
\text { Mott PHP with DE } \\
\text { Radioactive: } \\
\text { NCAW: } \\
\text { Mott PHP with DE }\end{array}$ & $\begin{array}{l}\text { Sludge Coarse Separation: } \\
\text { Settling/Clarification } \\
\text { Counter-current decantation } \\
\text { Crossflow metal filters } \\
\text { Crossflow metal/ceramic filter } \\
\text { Centrifuge } \\
\text { Crossflow ceramic filter } \\
\text { Sludge Polishing Separation: } \\
\text { Crossflow metal/ceramic filter } \\
\text { Crossflow metal filters } \\
\text { Deep bed Filter } \\
\text { IX Influent Polishing Separation: } \\
\text { Crossflow metal filters } \\
\text { Crossflow metal/ceramic filter } \\
\text { Deep bed Filter } \\
\text { Crossflow ceramic filter } \\
\text { Post-IX Guard: } \\
\text { Backflushable polymer filter } \\
\text { Backflushable s.s. filter }\end{array}$ \\
\hline
\end{tabular}


Table 6

Waste Composition and Treatment Methods for ORNL Gunite Tanks

\begin{tabular}{|c|c|c|c|}
\hline Waste & Composition & SLS Methods Tested & $\begin{array}{l}\text { SLS Methods Recommended } \\
\text { for Testing and Evaluation }\end{array}$ \\
\hline $\begin{array}{l}\text { ORNL } \\
\text { Gunite } \\
\text { Tanks } 49\end{array}$ & $\begin{array}{l}\text { Insoluble } \\
\text { solids: } \sim 10 \text { vol } \% \\
\text { pH }=9-11 \\
\text { principal components: } \\
\mathrm{Al}, \mathrm{Ca}, \mathrm{Na} \text {, } \\
\mathrm{U}, \mathrm{Fe}, \mathrm{Si} \text {, } \\
\mathrm{CO}_{3}^{-}, \mathrm{PO}_{4}^{-3}, \mathrm{NO}_{3}^{-}, \mathrm{SO}_{4}=\end{array}$ & $\begin{array}{l}\text { Simulants: } \\
\text { nonea }\end{array}$ & $\begin{array}{l}\text { Settling } \\
\text { Hydrocyclone } \\
\text { Crossflow s.s. filter } \\
\text { Crossflow ceramic/metal filter } \\
\text { Crossflow ceramic filter }\end{array}$ \\
\hline & $\begin{array}{l}\text { Principal radioactive } \\
\text { components: } \\
\text { Cs-137 (14 } \mathrm{mCi} / \mathrm{L}) \\
\mathrm{Sr}-90(24 \mathrm{mCi} / \mathrm{L})\end{array}$ & & \\
\hline
\end{tabular}

a The MVST filtration studies 37,38 are related 
Table 7

Waste Composition and Treatment Methods for ORNL MVST TRU Processing Facility

\begin{tabular}{|c|c|c|c|}
\hline Waste & Composition & SLS Methods Tested & $\begin{array}{l}\text { SLS Methods Recommended } \\
\text { for Testing and Evaluation }\end{array}$ \\
\hline $\begin{array}{l}\text { ORNL } \\
\text { MVST } \\
\text { sludge } 43\end{array}$ & $\begin{array}{l}\text { Insoluble } \\
\text { solids: } 23 \text { wt } \% \\
\text { pH }=7-13 \\
\text { principal components: } \\
\mathrm{Al}, \mathrm{Na}, \mathrm{Ca}, \mathrm{Th}, \mathrm{U}, \mathrm{K} \\
\mathrm{OH}^{-}, \mathrm{CO}_{3}^{-}, \mathrm{NO}_{3}^{-}, \mathrm{Cl}\end{array}$ & $\begin{array}{l}\text { Simulants: } \\
\text { Mott stainless steel crossflow } \\
\text { Radioactive: } \\
\text { Mott stainless steel crossflow }\end{array}$ & $\begin{array}{l}\text { Settling/Clarification } \\
\text { Counter-current decantation } \\
\text { Crossflow metal filters } \\
\text { Crossflow metal/ceramic filter } \\
\text { Centrifuge }\end{array}$ \\
\hline & $\begin{array}{l}\text { Principal radioactive } \\
\text { components: } \\
\text { Cs-137, Eu-152 } \\
\text { Sr-90, Pu }\end{array}$ & & \\
\hline
\end{tabular}


Table 8

Waste Composition and Treatment Methods for ORNL MVST Cesium Removal

\begin{tabular}{|c|c|c|c|}
\hline Waste & Composition & SLS Methods Tested & $\begin{array}{l}\text { SLS Methods Recommended } \\
\text { for Testing and Evaluation }\end{array}$ \\
\hline $\begin{array}{l}\text { ORNL } \\
\text { MVST } \\
\text { Cesium } \\
\text { Removal } 8\end{array}$ & $\begin{array}{l}\text { Insoluble } \\
\text { solids: }<0.01 \text { wt } \% \\
\text { pH }=7-13 \\
\text { principal components: } \\
\mathrm{Na}, \mathrm{K}, \mathrm{Al} \\
\mathrm{OH}^{-}, \mathrm{CO}_{3}^{-}, \mathrm{NO}_{3}^{-}, \mathrm{Cl} \\
\text { Principal radioactive } \\
\text { components: } \\
\text { Cs-137 }(5.95 \mathrm{mCi} / \mathrm{L}) \\
\mathrm{Sr}-90(0.19 \mathrm{mCi} / \mathrm{L})\end{array}$ & $\begin{array}{l}\text { Simulants: } \\
\text { Cartridge filters } \\
\text { Radioactive: } \\
\text { Cartridge filters }\end{array}$ & $\begin{array}{l}\text { Backflushable polymer filter } \\
\text { Backflushable metal filter }\end{array}$ \\
\hline
\end{tabular}

$<0.01$ wt $\%$ insoluble solids is after pH adjustment and settling in the MVST 
Table 9

Waste Composition and Treatment Methods for ORNL REDC

SLS Methods Recommended

Waste Composition

SLS Methods Tested for Testing and Evaluation

ORNL

Insoluble 34

Simulants:

REDC

solids: 0.2 wt $\%$

Mott stainless steel crossflow

Crossflow metal filters

$0.5-2 \mathrm{M} \mathrm{NaOH}$

Crossflow metal/ceramic

principal components:

$\mathrm{Al}, \mathrm{Fe}, \mathrm{Zr}, \mathrm{Na}$,

$\mathrm{OH}^{-}, \mathrm{NO}_{3}{ }^{-}$

Principal radioactive

components:

Cs-137/134 (10 Ci/L $\max .)^{\mathrm{a}}$

mixed fission

products $(1 \mathrm{Ci} / \mathrm{L} \max )^{\mathrm{a}}$

Comments:

a Highly variable range 
Table 10

Waste Composition and Treatment Methods for ORNL NGLLLW

$\begin{array}{lll}\text { Waste } & \text { Composition } & \text { SLS Methods Tested } \\ \text { ORNL } & \text { Insoluble } 8 & \text { Simulants: } \\ \text { NGLLLW } & \text { solids: }<0.02 \text { wt } \% & \text { Laboratory centrifuge } \\ & \mathrm{pH}=-13 & \\ & \text { principal components: } \\ & \mathrm{Al}, \mathrm{Li}, \mathrm{Na}, \\ & \mathrm{CO}_{3}^{-}, \mathrm{OH}^{-}, \mathrm{NO}_{3}^{-}, \mathrm{SO}_{4}= \\ & \text { Principal radioactive } \\ & \text { components: } \\ & \mathrm{Cs}-137(100 \mathrm{mCi} / \mathrm{L}) \\ & \mathrm{Ru}-106 / 103 \quad(130 \mathrm{mCi} / \mathrm{L}) \\ & \mathrm{Sr}-90(19.5 \mathrm{mCi} / \mathrm{L})\end{array}$

SLS Methods Recommended

Sr Precipitation Step:

Crossflow metal filters

Crossflow ceramic filter

Crossflow ceramic/metal filter

Backflushable s.s. filter

First KCCF Strike:

Crossflow ceramic filter

Crossflow ceramic/metal filter

Crossflow metal filters

Second KCCF Strike:

Backflushable s.s filter w/ DE

Backflushable polymer filter 
F \&. H LIFT STATION INFLUENTS

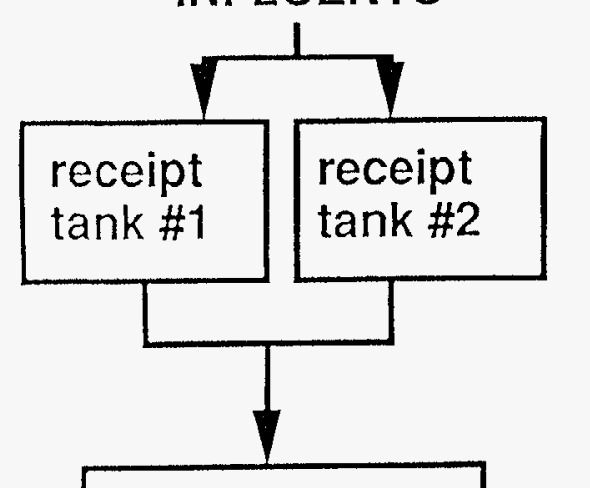

$\mathrm{pH}$ ADJUSTMENT

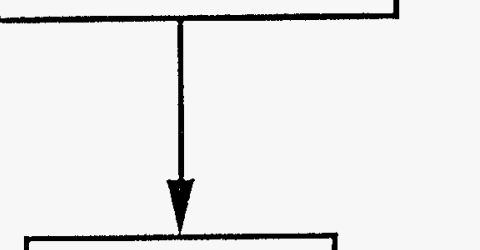

Figure 1.

F/H-AREA EFFLUENT TREATMENT FACILITY PROCESS FLOWSHEET
NPDES OUTFALL

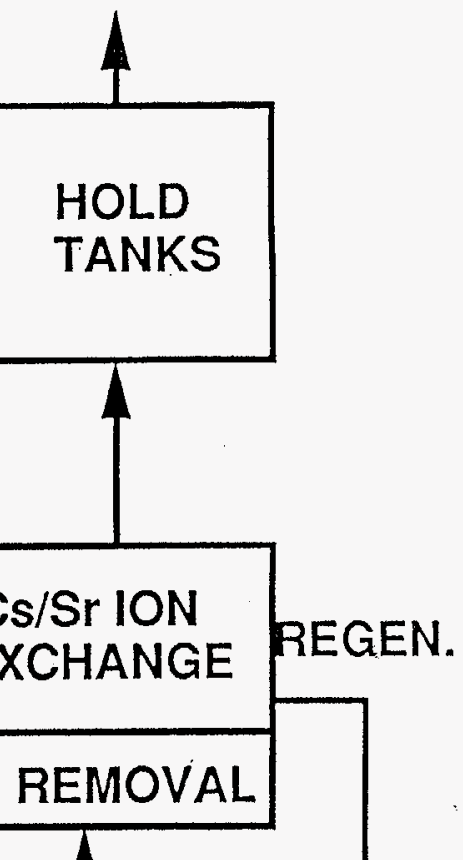

8

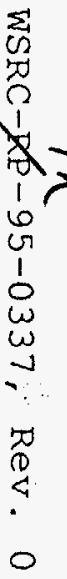


Figure 2. SRS HIGH LEVEL WASTE FLOWSHEET

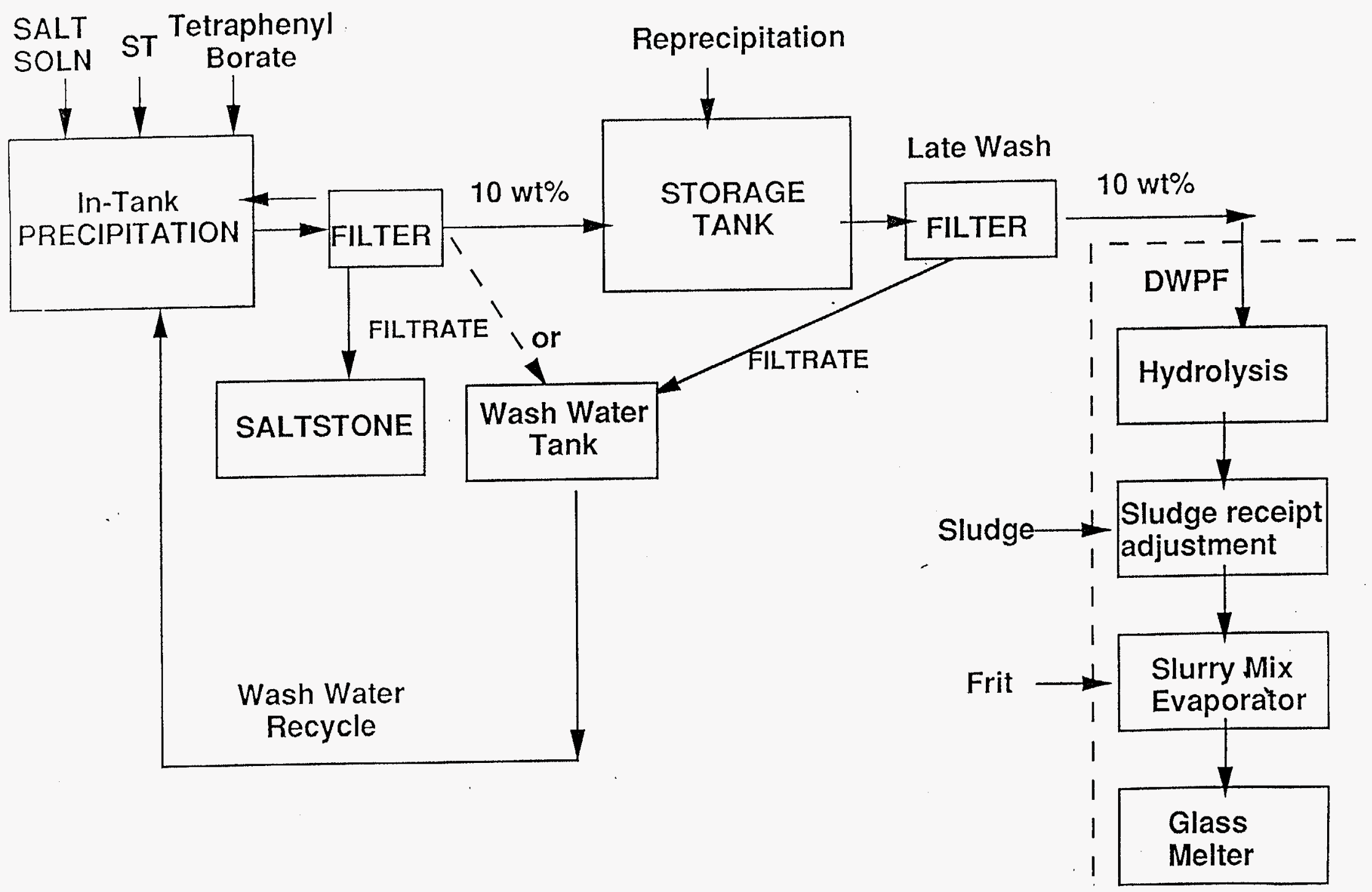




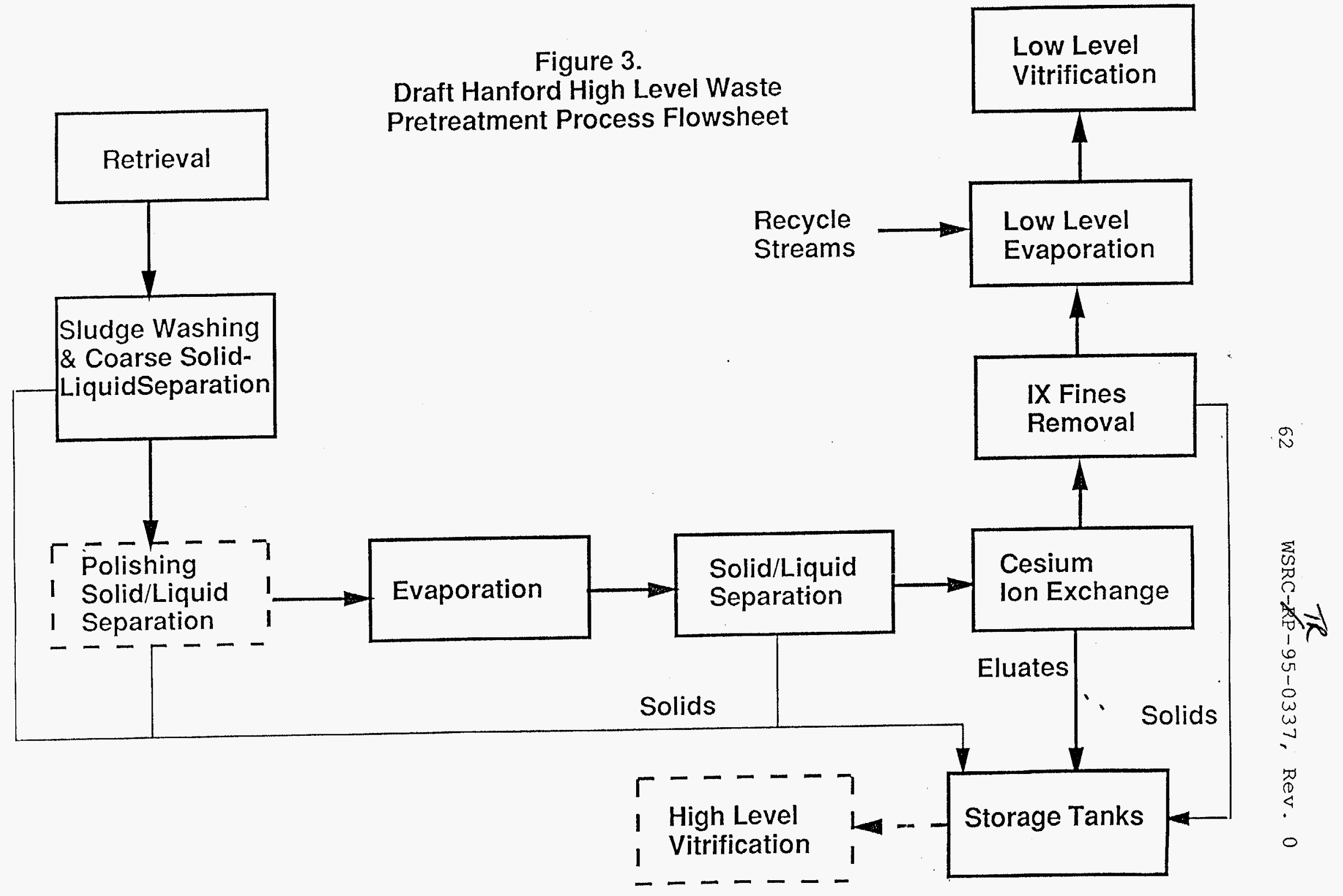


Figure 4.

Oak Ridge Radiochemical Engineering

Development Center Waste Process Flowsheet

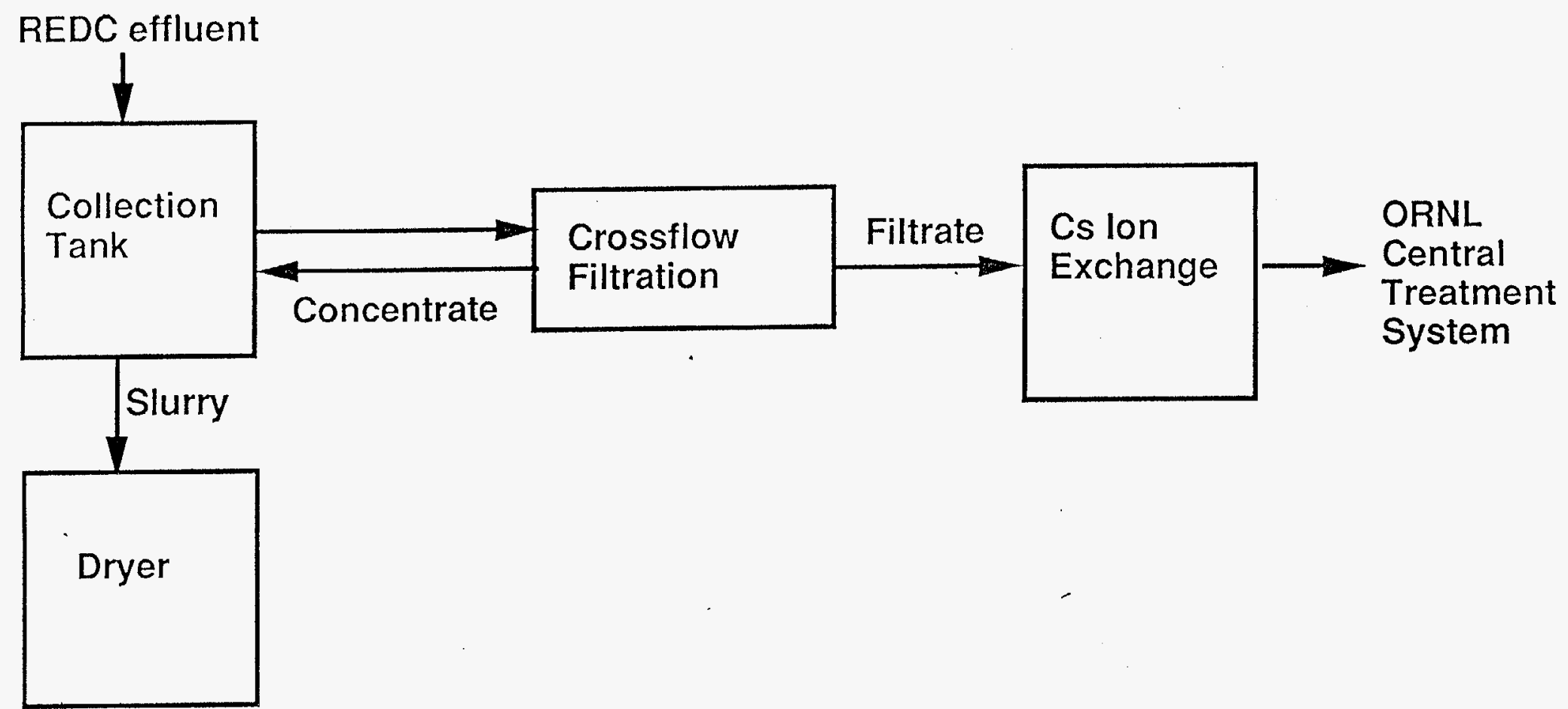




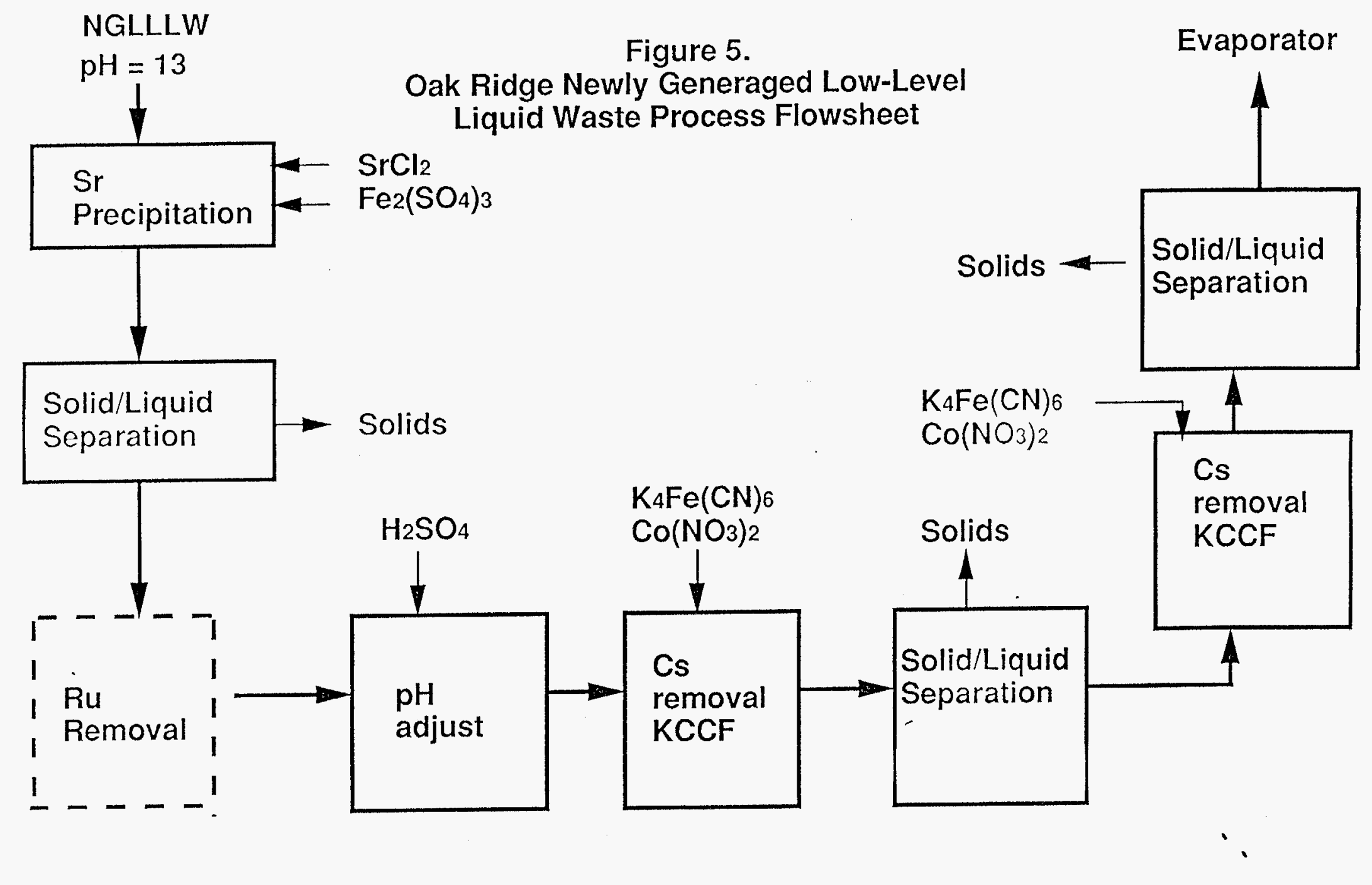

